\title{
Cannabidiol and Oxygen-Ozone Combination Induce Cytotoxicity in Human Pancreatic Ductal Adenocarcinoma Cell Lines
}

\author{
Margherita Luongo ${ }^{1,+}$, Oliviero Marinelli ${ }^{2,+}+{ }^{+}$, Laura Zeppa ${ }^{2}$, Cristina Aguzzi ${ }^{2}$, \\ Maria Beatrice Morelli ${ }^{2}{ }^{D}$, Consuelo Amantini ${ }^{3}$, Andrea Frassineti ${ }^{1}$, Marianne di Costanzo ${ }^{1}$, \\ Alessandro Fanelli ${ }^{4}$, Giorgio Santoni ${ }^{2}$ and Massimo Nabissi ${ }^{2,5, * \text { (D) }}$ \\ 1 "Maria Guarino" Foundation-AMOR No Profit Association, 80078 Pozzuoli, Italy; \\ margherita.luongo@aslnapoli2nord.it (M.L.); info@dottorfrassineti.it (A.F.); \\ marianne.dicostanzo@ospedalideicolli.it (M.d.C.) \\ 2 School of Pharmacy, University of Camerino, 62032 Camerino (MC), Italy; \\ oliviero.marinelli@unicam.it (O.M.); laura.zeppa@studenti.unicam.it (L.Z.); \\ cristina.aguzzi@studenti.unicam.it (C.A.); mariabeatrice.morelli@unicam.it (M.B.M.); \\ giorgio.santoni@unicam.it (G.S.) \\ 3 School of Bioscience and Veterinary Medicine, University of Camerino, 62032 Camerino (MC), Italy; \\ consuelo.amantini@unicam.it \\ 4 Department of Radiotherapy, Ecomedica Empoli, 50053 Empoli FI, Italy; alessandro.fanelli@ecomedica.it \\ 5 Integrative Therapy Discovery Lab, University of Camerino, 62032 Camerino (MC), Italy \\ * Correspondence: massimo.nabissi@unicam.it; Tel.: +39-0737-403306 \\ + These authors have equally contributed to this work.
}

Received: 10 June 2020; Accepted: 24 September 2020; Published: 27 September 2020

Simple Summary: Pancreatic cancer (PC) is related to lifestyle risks, chronic inflammation, and germline mutations. Surgical resection and adjuvant chemotherapy are the main therapeutic strategies but are less effective in patients with high-grade tumors. Oxygen-ozone $\left(\mathrm{O}_{2} / \mathrm{O}_{3}\right)$ therapy is an emerging alternative tool for the treatment of several clinical disorders. The advantages of using cannabinoids have been evaluated in several human cancers. Regarding PC, activation of cannabinoid receptors was found to induce PC cell apoptosis without affecting the normal pancreas cells. Herein, we evaluate the anticancer effect of cannabidiol (CBD) and $\mathrm{O}_{2} / \mathrm{O}_{3}$, alone or in combination, on two human pancreatic ductal adenocarcinoma (PDAC) cell lines, PANC-1 and MiaPaCa-2, examining expression profiles of 92 pancreatic adenocarcinoma associated genes, cytotoxicity, migration properties, and cell death. Finally, we assess the combination effects with gemcitabine and paclitaxel. Summarizing, for the first time the antitumoral effect of combined therapy with CBD and oxygen-ozone therapy in PDAC is evidenced.

Abstract: Pancreatic cancer (PC) is related to lifestyle risks, chronic inflammation, and germline mutations in BRCA1/2, ATM, MLH1, TP53, or CDKN2A. Surgical resection and adjuvant chemotherapy are the main therapeutic strategies but are less effective in patients with high-grade tumors. Oxygen-ozone $\left(\mathrm{O}_{2} / \mathrm{O}_{3}\right)$ therapy is an emerging alternative tool for the treatment of several clinical disorders. $\mathrm{O}_{2} / \mathrm{O}_{3}$ therapy has been found to ameliorate mechanisms promoting chronic pain and inflammation, including hypoxia, inflammatory mediators, and infection. The advantages of using cannabinoids have been evaluated in vitro and in vivo models of several human cancers. Regarding PDAC, activation of cannabinoid receptors was found to induce pancreatic cancer cell apoptosis without affecting the normal pancreas cells. In a murine model of PDAC, a combination of cannabidiol (CBD) and gemcitabine increased survival length by nearly three times. Herein, we evaluate the anticancer effect of $\mathrm{CBD}$ and $\mathrm{O}_{2} / \mathrm{O}_{3}$, alone or in combination, on two human PDAC cell lines, PANC-1 and MiaPaCa-2, examining expression profiles of 92 pancreatic adenocarcinoma associated genes, cytotoxicity, migration properties, and cell death. Finally, we assess the combination effects with 
gemcitabine and paclitaxel. Summarizing, for the first time the antitumoral effect of combined therapy with CBD and oxygen-ozone therapy in PDAC is evidenced.

Keywords: cannabidiol; oxygen-ozone; pancreatic cancer; cytotoxicity; migration; chemo-resistance; PDAC gene profile

\section{Introduction}

Pancreatic cancer (PC) is a lethal malignancy with a 5-year survival of approximately 5-9\% [1,2]. The most common and aggressive type, among pancreatic malignancies, is pancreatic ductal adenocarcinoma (PDAC), an infiltrating neoplasm with glandular differentiation, that is the fourth cause of cancer related death worldwide [2-4]. The development of PDAC is related to environmental and lifestyle risks, but also pathological conditions linked to chronical inflammations and, for a subgroup of PDAC patients, germline mutations in Breast Cancer Type 1/2 (BRCA1/2), ATM Serine/Threonine Kinase $(A T M)$, MutL Homolog 1 gene (MLH1), TP53 or Cyclin Dependent Kinase Inhibitor 2A (CDKN2A) are considered further risk factors [5,6]. Indeed, somatic mutations as in oncogene (KRAS) and onco-suppressor genes (TP53, CDKN2A, SMAD Family Member 4 SMAD4), that support cancer aggressiveness, are important for the diagnosis of this malignant phenotype [2,7]. Pancreatic cancer hardly responds to chemotherapy or immunotherapy, and surgery is usually not an option in most patients [8]. Indeed, surgical resection followed by adjuvant chemotherapy is the main therapeutic strategy for the $10-20 \%$ of patients with resectable PDAC stage, but is less effective in the rest of patients that show locally advanced, non-resectable stages or distant metastasis $[9,10]$. For these non-resectable patients, systemic chemotherapy is employed as first-line treatment, with different drugs as gemcitabine (GEM), capecitabine, 5-fluorouracil in monotherapy or in combination with radiotherapy [11]. New potential therapies such as immunotherapy based on checkpoint inhibitors and targeted therapy are under evaluation but actually these treatments showed limited efficacy and were unsuccessful in improving patients' survival, especially for metastastic pancreatic cancer $[4,12,13]$. These difficulties in treating PDAC are probably due to the special tumor-associated microenvironment. Unlike most other solid cancers, the pancreatic cancer microenvironment contains ample stromal cells, lacks vascularization, and cancer cells survive in long-term hypoxic conditions via special, but not completely identified, mechanisms [14]. Hypoxia has been reported to induce aggressive characteristics in many types of cancer, modulating different genes involved in cell proliferation, drug efflux, apoptosis, metabolism, autophagy, and angiogenesis, contributing to drug resistance [14,15]. Under hypoxia, tumor cells develop various mechanisms for evading apoptosis as over-expression of Mouse Double Minute Homolog (MDM2), the negative regulator of p53, leading to apoptosis resistance [16]. Moreover, hypoxic cells do not receive enough chemotherapeutic agents because they are distant from the capillary and because of abnormal vascularization of tumors [16]. Therefore, tumor hypoxia has been considered as a validated target for treating cancer $[17,18]$.

Oxygen/Ozone $\left(\mathrm{O}_{2} / \mathrm{O}_{3}\right)$ therapy is an emerging alternative tool for treatment of several clinical disorders, among them, ischemic disorder and tuberculosis. In the past, the use of $\mathrm{O}_{2} / \mathrm{O}_{3}$ in therapy was discouraged by orthodox medicine for the lack of solid scientific biological and clinical data [19]. Recently, some concerns have been practically overcome both at in vitro and in vivo level. $\mathrm{O}_{2} / \mathrm{O}_{3}$ has shown anti-inflammatory effects [20] and the improvement of muscle fatigue [21]. $\mathrm{O}_{2} / \mathrm{O}_{3}$ is a gas characterized by three atoms of oxygen with a cyclic structure and the medical generator of ozone produces it from pure oxygen passing through a high voltage gradient $(5-13 \mathrm{mV})$. One of the most important properties of $\mathrm{O}_{2} / \mathrm{O}_{3}$ administration is the increase in tissue oxygenation and ozone therapy, which has been found to ameliorate many of the mechanisms promoting chronic pain and inflammation, including hypoxia, inflammatory mediators, and infection [22]. In cancer, $\mathrm{O}_{2} / \mathrm{O}_{3}$ was found to inhibit the growth of different human tumor cells (breast, colon, ovarian) without affecting non-tumor cell lines 
and to potentiate the effect of chemotherapeutic drugs as 5-fluorouracil, cisplatin, and etoposide [23,24]. Advantages of using cannabinoids in cancer therapy have been evaluated in in vitro and in vivo models of several human cancers. Their potential use for cancer in current clinical trials has been recently reviewed [25]. Indeed, cannabinoids can reduce cancer cell viability, proliferation, metastasis, and they induce cancer cell death in human glioblastoma multiforme, multiple myeloma, colorectal cancer, endometrial cancer, prostate carcinoma, and melanoma [26-29]. Cannabidiol (CBD), the main non-psychotropic cannabinoid, has been demonstrated to interact with cannabinoid receptors (CB1, CB2), G Protein-Coupled Receptor 55 (GPR55), with transient potential receptors belonging to vanilloid subfamily (TRPV1, TRPV2, TRPV3, TRPV4), Transient Receptor Potential Ankyrin 1 (TRPA1), Transient Receptor Potential Melastatin 8 (TRPM8), with peroxisome proliferator-activated receptor (PPAR $\gamma$ ), but it can also act in an unknown independent-receptors manner [26,30]. Regarding PDAC, activation of cannabinoid receptors, particularly CB2, was found to induce pancreatic cancer cell apoptosis without affecting the normal pancreas cells [31] and different synthetic receptor agonists, as WIN-55,212-2 (CB1 and CB2), ACEA (CB1), and JWH-015 (CB2), caused a substantial cell death of MiaPaCa-2 cell [32]. In vivo study demonstrated that a combination of CBD (as GPR55 antagonist) and GEM in murine model of pancreatic cancer, increased a survival nearly three times longer, compared to mice treated with vehicle or GEM alone [33]. Similar findings were shown in a study with the CB1 ligand SR141716 combined with GEM, where was evidenced a reduced tumor growth in treated mice with respect to control and single agent treated mice [34]. As to $\mathrm{O}_{2} / \mathrm{O}_{3}, \mathrm{CBD}$ exerts a synergistic activity with different chemotherapeutic drugs $[25,26]$. So, the aim of this research was to investigate, for the first time, the anticancer effect of $\mathrm{CBD}$ and $\mathrm{O}_{2} / \mathrm{O}_{3}$, alone and in combination, on two human PDAC cell lines, PANC-1 and MiaPaCa-2, by examining expression profiles of 92 pancreatic adenocarcinoma associated genes, cytotoxicity, migration properties, and cell death. Finally, the effects of the combination with GEM and Paclitaxel (PTX), the main chemotherapeutical drugs used in pancreatic cancer therapy, were assessed.

\section{Results}

\subsection{Expression of CBD Target Receptors in PDAC Cell Lines}

The gene and protein expressions of CB1, CB2, TRPV1, TRPV2, TRPV3, TRPV4, TRPA1, and TRPM8 were evaluated in PANC- 1 and MiaPaCa-2 cancer cell lines by qRT/PCR and Western Blot analysis. Overall, gene and protein expression showed that $\mathrm{CB} 1$ and $\mathrm{CB} 2$ receptors are expressed in both cell lines without any significant difference for the $\mathrm{CB} 1$ receptor, while the $\mathrm{CB} 2$ protein level is higher in the PANC-1 cell line. Regarding the expression profile of the TRP members analyzed, PDAC cells express all CBD targets belonging to this family, both at mRNA and at protein levels. Moreover, TRPV3 and TRPV4 proteins are highly expressed in both PDAC cell lines, especially in MiaPaCa-2 cells, and TRPV2 is expressed mainly in the PANC-1 cell line. Additionally, at protein levels, TRPM8 is expressed more in PANC-1 cells while TRPA1 is not expressed in both PDAC cell lines (Figure S1A,B). Summarizing, PDAC cells express significant levels of most of the CBD target receptors and the difference observed between PANC-1 and MiaPaCa-2 cell lines could suggest a different response to CBD.

\subsection{CBD is More Effective in Reducing Cell Viability in PDAC Cell Lines than in Normal Cells}

The cytotoxic effect of CBD was evaluated in PANC-1 and MiaPaCa-2 cancer cell lines and in two normal cell lines H6c7 and NHF, by 3-[4,5-dimethylthiazol-2-yl]-2,5 diphenyl tetrazolium bromide (MTT) assay. Cells were treated with different doses of CBD (from 1.52 to $100 \mu \mathrm{M}$ ) with daily administration up to $72 \mathrm{~h}$. The results showed that cell viability is reduced in a dose-dependent manner with an $\mathrm{IC}_{50}$ of $20.3 \pm 0.4 \mu \mathrm{M}$ for PANC-1 and an $\mathrm{IC}_{50}$ of $18.6 \pm 1.2 \mu \mathrm{M}$ for MiaPaCa-2 (Figure 1), indicating a major sensitivity of MiaPaCa-2 with respect to PANC-1, while H6c7 and NHF cell line results showed less sensitivity to $\mathrm{CBD}$ (Figure S2). According to $\mathrm{IC}_{50}$ values, we decided to use $\mathrm{CBD}$ at 12.5 and $25 \mu \mathrm{M}$, in daily administration, for the next experiments. 
PANC-1

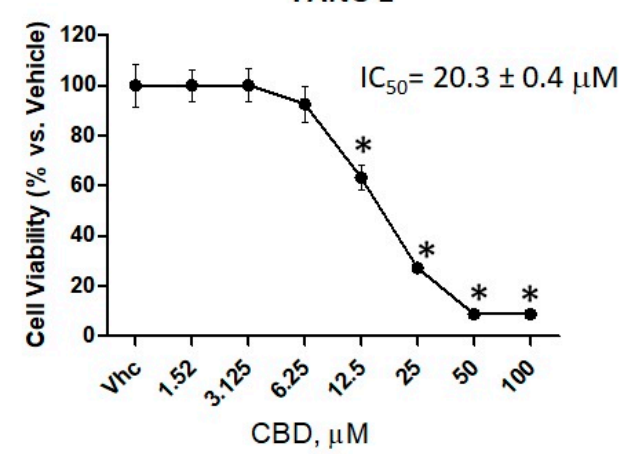

MiaPaCa-2

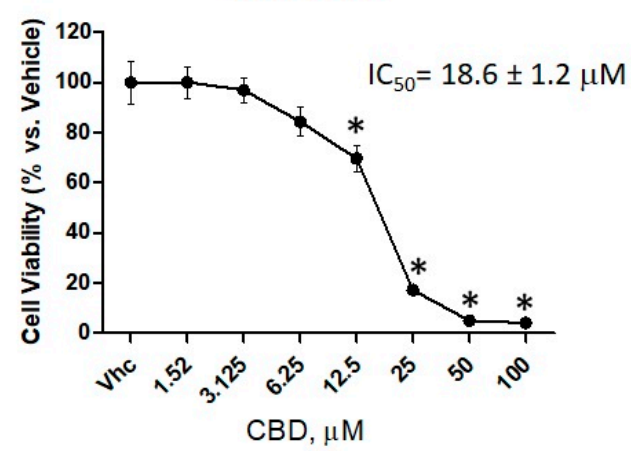

Figure 1. Cannabidiol (CBD) induced cytotoxicity in PDAC cell lines. Cell viability was determined by 3-[4,5-dimethylthiazol-2-yl]-2,5 diphenyl tetrazolium bromide (MTT) assay. PANC-1 and MiaPaCa-2 cells were treated for $72 \mathrm{~h}$ with different concentrations of CBD (up to $100 \mu \mathrm{M}$ ), in daily administration.

Data shown are expressed as mean \pm SE of three separate experiments. ${ }^{*} p<0.05$ treated vs. vehicle.

\subsection{CBD Induces Apoptotic Cell Death in PDAC Cancer Cell Lines}

To assess cell death, FITC-conjugated Annexin V and Propidium Iodide (PI) staining and cytofluorimetric analysis were used. After $48 \mathrm{~h}$ of daily treatment with CBD (12.5-25 $\mu \mathrm{M})$, it was observed that CBD induces an increased percentage of cells undergoing apoptosis compared to control, in both cell lines. PANC-1 and MiaPaCa-2 showed a significant increase in apoptotic cell death with CBD $25 \mu \mathrm{M}$ compared to $12.5 \mu \mathrm{M}$ (Figure 2).

\section{PANC-1}

CBD $12.5 \mu \mathrm{M}$

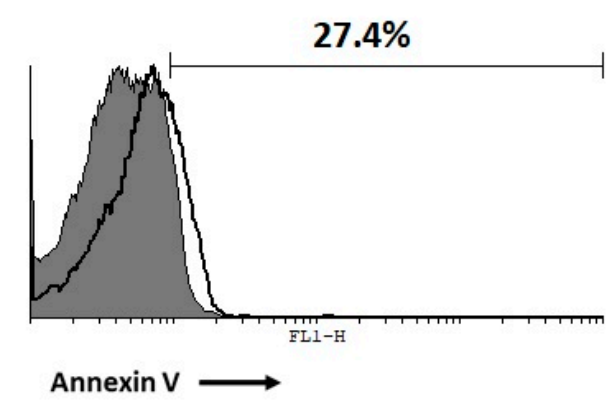

CBD $12.5 \mu \mathrm{M}$

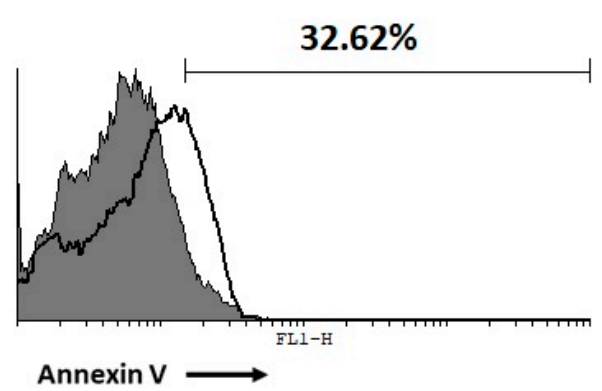

CBD $25 \mu \mathrm{M}$

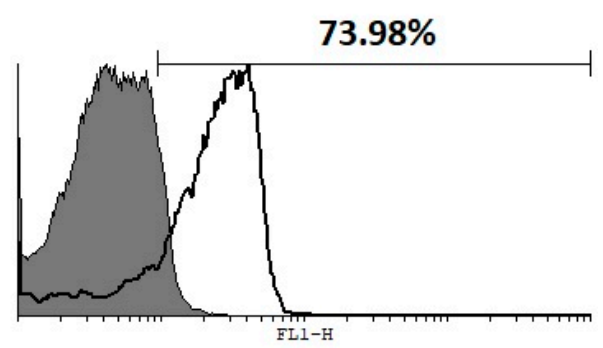

MiaPaCa-2

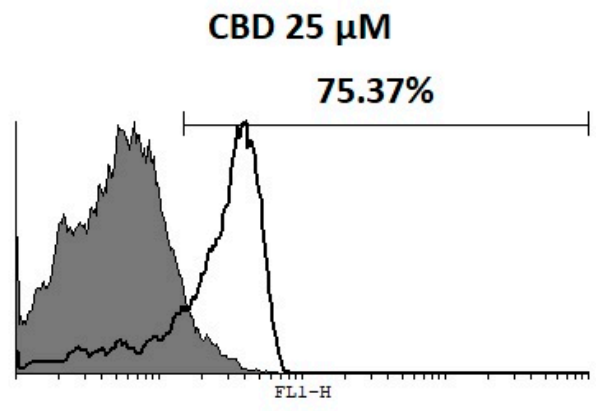

Figure 2. CBD induced cell death in pancreatic ductal adenocarcinoma (PDAC) cell lines. PDAC cell lines were treated with CBD for $48 \mathrm{~h}$. Flow cytometric analysis was performed by Annexin V/Propidium Iodide (PI) staining. Data represent the percentage of Annexin V positive cells and are representative of one of three separate experiments. 
To confirm apoptosis, Caspase 3 (Casp3) activation was evaluated, by Western Blot analysis. Cells were treated with CBD $25 \mu \mathrm{M}$ for $48 \mathrm{~h}$ in daily administration and the results confirm an increase in activated Casp3 in both cell lines, especially in MiaPaCa-2 cells (Figure 3A). Moreover, by Comet assay analysis, we confirmed that the CBD $25 \mu \mathrm{M}$ after $48 \mathrm{~h}$ of treatment induced DNA damage (Figure 3B).

A
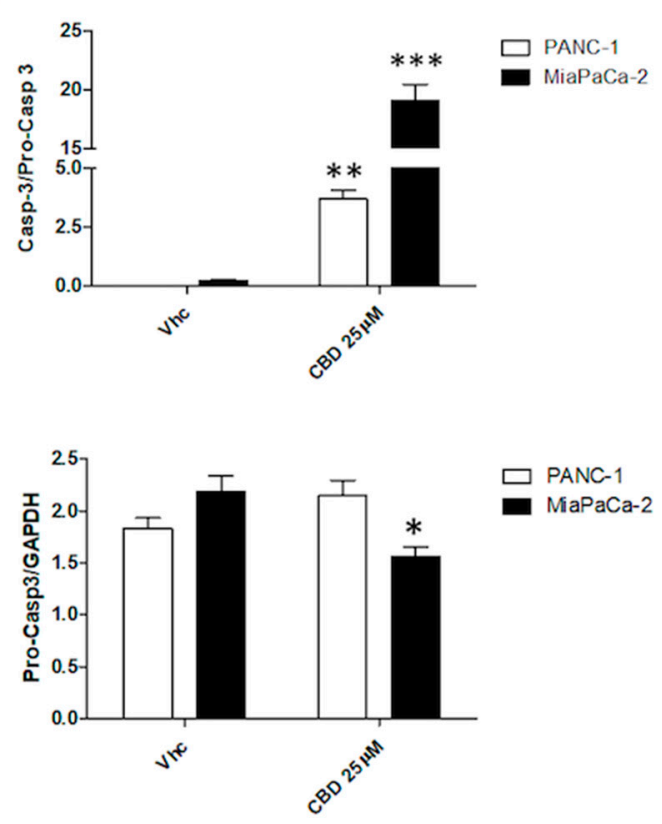

Pro-Casp3 $35 \mathrm{kDa}$

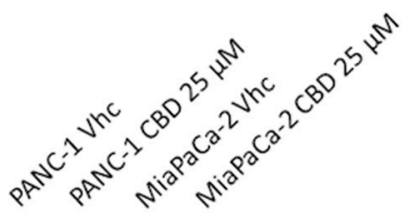

Casp-3 $17 \mathrm{kDa}$

GAPDH $37 \mathrm{kDa}$

CBD $25 \mu \mathrm{M}$

PANC-1
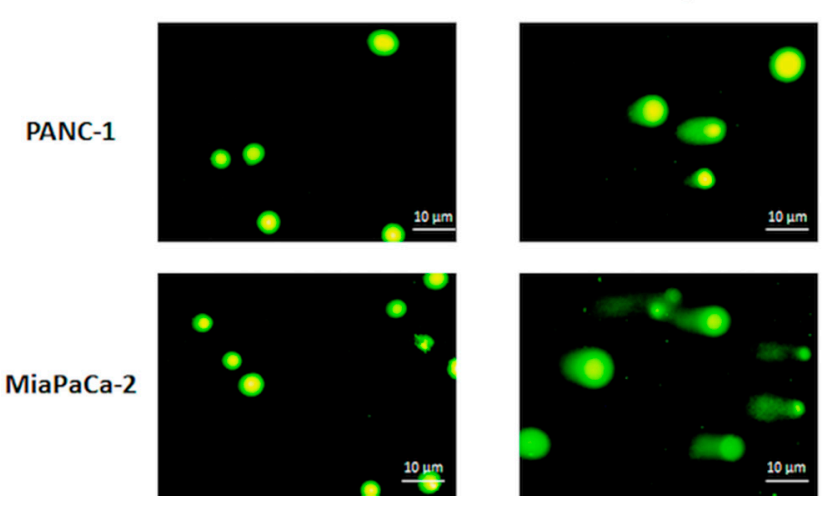

Figure 3. CBD induced apoptotic cell death in PDAC cell lines. PDAC cell lines were treated with CBD for $48 \mathrm{~h}$. (A) Western blot analysis and densitometric quantification of Casp-3 protein levels. Pro-Casp3 densitometric values were normalized to Glyceraldehyde 3-phosphate dehydrogenase (GAPDH) used as loading control, Casp-3 densitometric values were normalized to Pro-casp3. Blots are representative of one of three separate experiments, ${ }^{*} p<0.05,{ }^{* *} p<0.01,{ }^{* * *} p<0.001$ treated vs. untreated cells. The whole western blot image can be found in Figure S11. (B) Cell damage and DNA fragmentation were determined on PANC-1 and MiaPaCa-2 cells untreated (Vehicle Vhc) and treated with CBD for $48 \mathrm{~h}$ by Comet assay (alkaline electrophoresis conditions $20 \mathrm{~V}$ for $10 \mathrm{~min}$, image acquisition $10 \mathrm{x}$ ).

\subsection{CBD Reduces Cell Migration of PDAC Cell Lines}

To examine the role of CBD in regulating migration of PANC-1 and MiaPaCa-2 cells, the wound-healing assay was performed. The results showed that CBD $12.5 \mu \mathrm{M}$, does not induce a significant effect in cell migration after $24 \mathrm{~h}$ of treatment, while at $48 \mathrm{~h}$, a reduction of cell migration is observed in both cell lines (Figure 4). These data suggested that CBD influences PDAC cell line migration. 
PANC-1

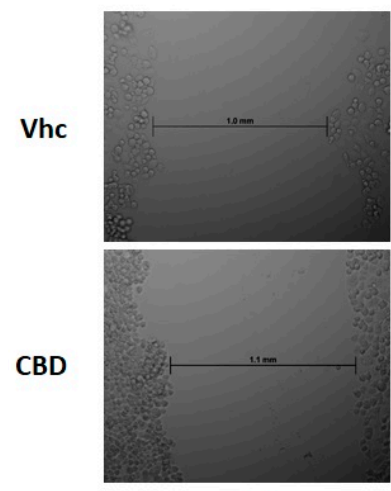

$\mathbf{O h}$

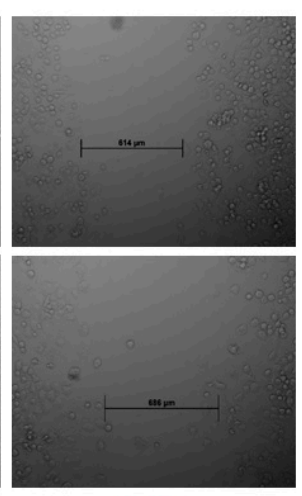

$48 \mathrm{hs}$

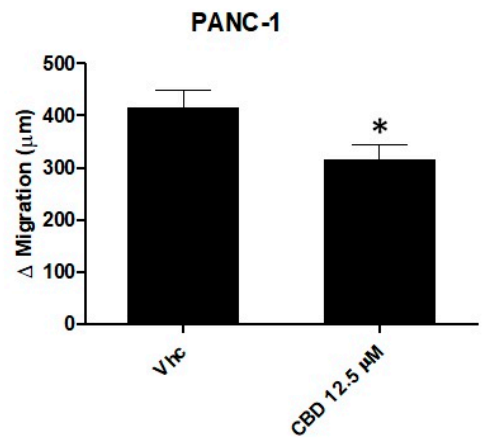

MiaPaCa-2

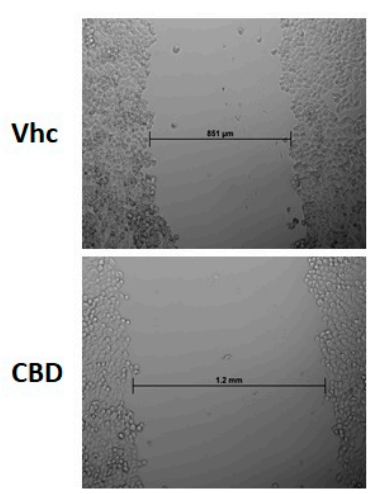

$\mathbf{O h}$

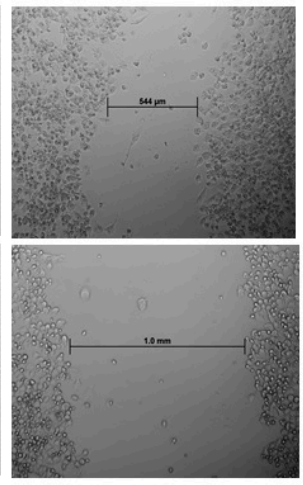

48 hs

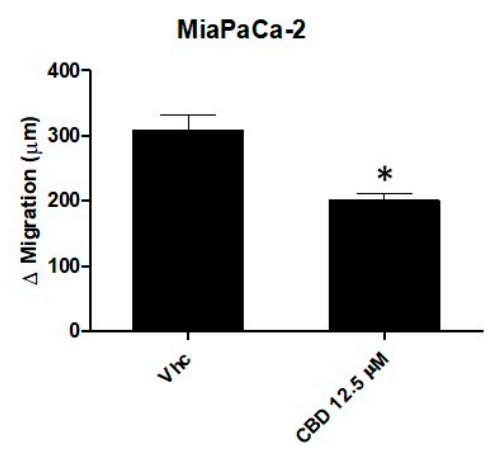

Figure 4. CBD treatment inhibits migration of PDAC cells. Representative image of wound-healing assays for PANC-1 and MiaPaCa-2 cells after treatment with CBD $12.5 \mu \mathrm{M}$ for up $48 \mathrm{~h}$. All experiments were repeated three times and images were taken at 0 and $48 \mathrm{~h}(10 \times)$. Data are presented as the mean \pm SE. ${ }^{*} p<0.05$ vs. Vhc.

\subsection{CBD Increases Chemosensitivity in PDAC Cell Lines}

In order to evaluate a synergistic effect between CBD and the most common chemotherapeutic drugs used in PDAC treatment, GEM (up to $800 \mu \mathrm{M}$ ) and PTX (up to $28 \mu \mathrm{M}$ ) were tested in both cell lines. The results evidenced that MiaPaCa-2 cells are more sensitive to GEM and PTX than PANC-1 and that PTX shows a higher cytotoxic effect than GEM, in both cell lines (PANC-1 GEM $\mathrm{IC}_{50}: 143.8 \pm 2.4 \mu \mathrm{M}$; PTX $33.57 \pm 1.2 \mathrm{nM}$, MiaPaCa-2 GEM IC ${ }_{50}: 63.6 \pm 3.5 \mu \mathrm{M}$; PTX $21.18 \pm 1.1 \mathrm{nM}$ ) (Figure 5), at $72 \mathrm{~h}$ post-treatments. 


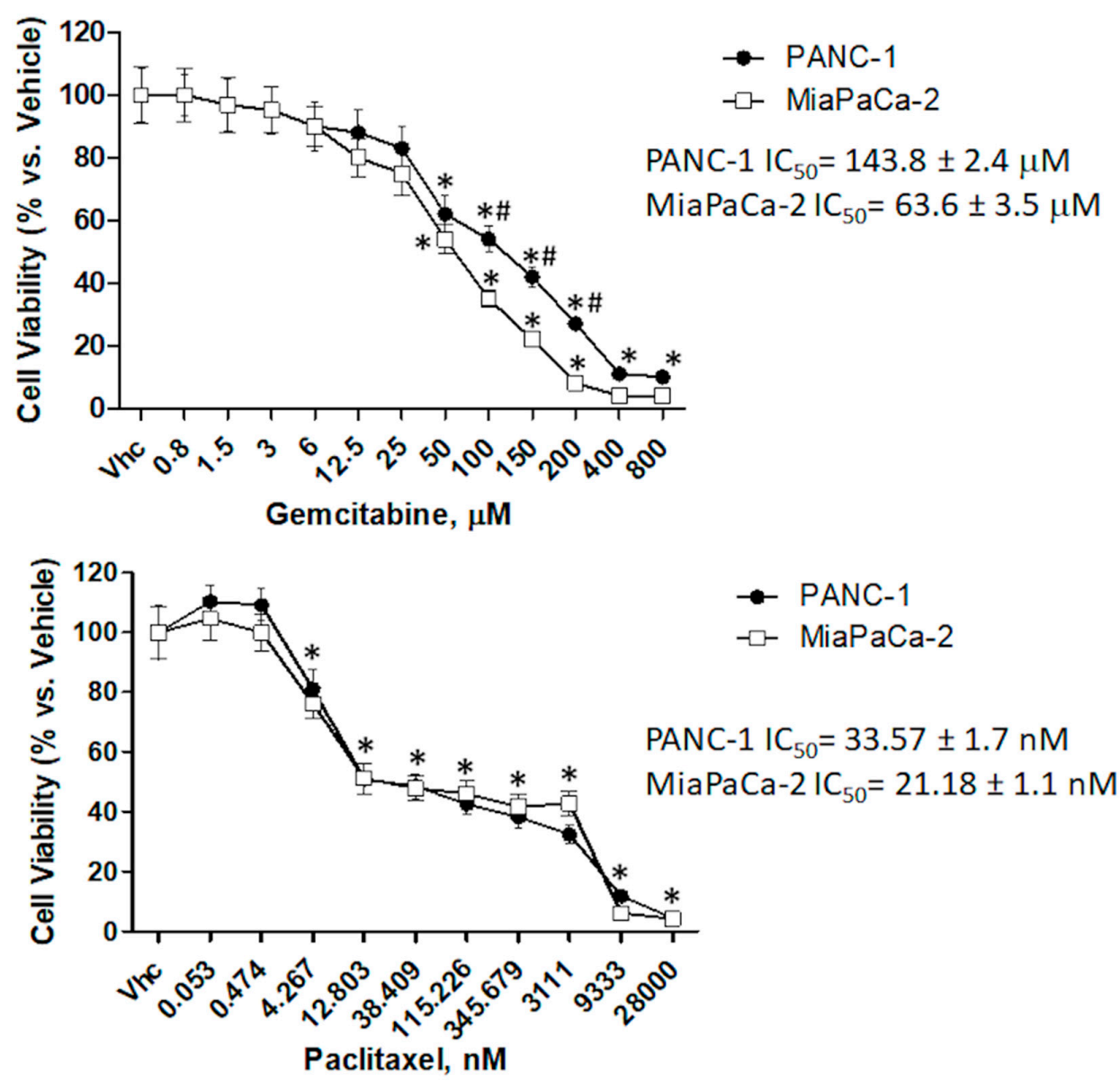

Figure 5. Cytotoxic effect of chemotherapeutic drugs in PDAC cell lines. Cell viability was determined by MTT assay. PANC-1 and MiaPaCa-2 cells were treated for $72 \mathrm{~h}$ with different concentrations of gemcitabine (GEM) (up to $800 \mu \mathrm{M}$ ) or paclitaxel (PTX) (up to $28 \mu \mathrm{M}$ ), in single administration. Data shown are expressed as mean $\pm \mathrm{SE}$ of three separate experiments. ${ }^{*} p<0.05$ treated vs. vehicle, \# $p<0.05$ PANC-1 vs. MiaPaCa-2.

Subsequently, PDAC cell lines were exposed to CBD at $6.25,12.5$, and $25 \mu \mathrm{M}$ in combination with three doses of each chemotherapeutic drug (GEM 100, 50, and $25 \mu \mathrm{M}$, and PTX 7, 3.5, and $1.75 \mu \mathrm{M}$ ) for $72 \mathrm{~h}$. Chemotherapeutic drugs were administered once, while CBD was administered daily. The results showed that CBD $6.25 \mu \mathrm{M}$, in combination with all tested doses of GEM and PTX, did not increased cytotoxic effects compared with chemotherapeutic drugs alone, while CBD 12.5 and $25 \mu \mathrm{M}$ was able to increase the cytotoxic effect induced by both chemotherapeutic drugs alone (Figure 6). Indeed, synergistic effects were obtained with PTX $7 \mu \mathrm{M}$ especially in MiaPaCa-2 cells while, in PANC-1, this combination resulted in an additive effect. Combination with GEM $100 \mu \mathrm{M}$ induced an additive and synergistic effect with, respectively, CBD 12.5 and $25 \mu \mathrm{M}$, in MiaPaCa-2 but not in the PANC- 1 cell line (Figure S3). The results evidenced that $\mathrm{CBD}$, at the appropriate doses, should be useful to enhance the chemotherapeutic drugs effects. 
PANC-1

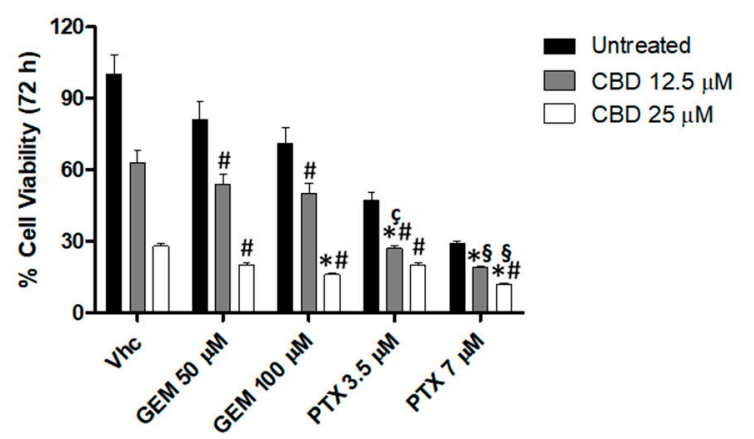

MiaPaCa-2

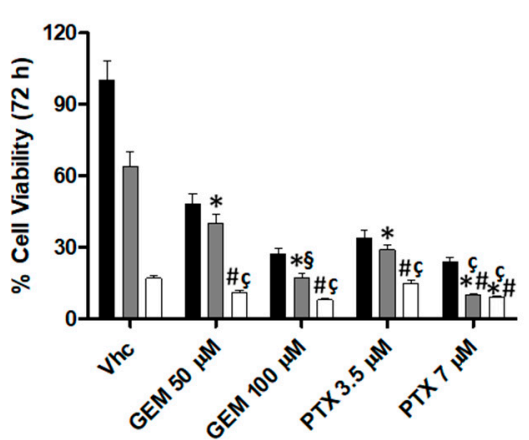

Untreated

CBD $12.5 \mu \mathrm{M}$ CBD $25 \mu \mathrm{M}$

Figure 6. CBD increases the cytotoxic effect of chemotherapeutic drugs in PDAC cell lines. CBD increases the cytotoxic effect of chemotherapeutic drugs in PDAC cell lines. Cell viability was determined in PDAC cell lines by MTT assay. Cells were treated for $72 \mathrm{~h}$ with CBD, alone and in combination with different doses of GEM and PTX. Data shown are expressed as mean \pm SE of three separate experiments. ${ }^{*} p<0.05$ vs. CBD alone, ${ }^{\#} p<0.05$ vs. chemotherapeutic drug alone, $\S$ for additive effect, $\varsigma$ for synergistic effect.

\section{6. $\mathrm{O}_{2} / \mathrm{O}_{3}$ Treatment Improves $\mathrm{CBD}$ Cell Cytotoxicity in PDAC Cells}

The effect of $\mathrm{O}_{2} / \mathrm{O}_{3}$ on PDAC cell lines was evaluated by using a hypoxia chamber. PANC- 1 and MiaPaCa-2 cell lines were daily treated with $\mathrm{O}_{2} / \mathrm{O}_{3}$ and cell viability, with respect to cells cultured in normoxia, was evaluated up to $72 \mathrm{~h}$, by MTT. Additionally, the effect of CBD administration in $\mathrm{O}_{2} / \mathrm{O}_{3}$-treated cell lines was evaluated. The results showed that the addition of $\mathrm{O}_{2} / \mathrm{O}_{3}$ strongly reduces cell viability, as observed starting from $24 \mathrm{~h}$ post-treatment, and the effect of $\mathrm{O}_{2} / \mathrm{O}_{3}$ was increased by $\mathrm{CBD}$ in a dose and time dependent manner, in both cell lines (Figure 7).

PANC-1

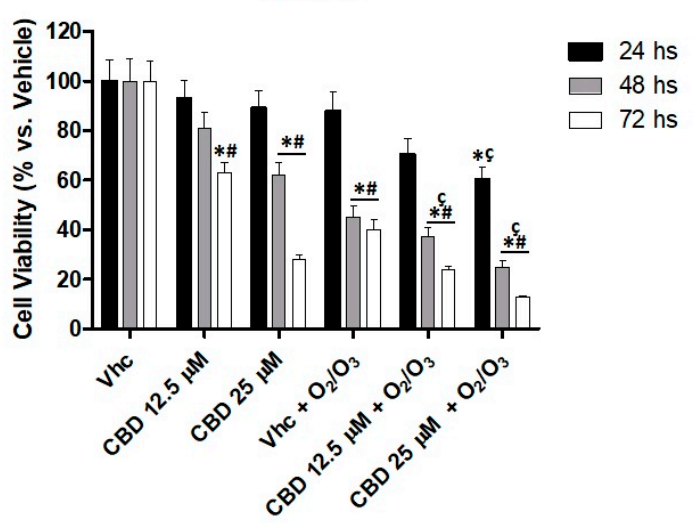

MiaPaCa-2

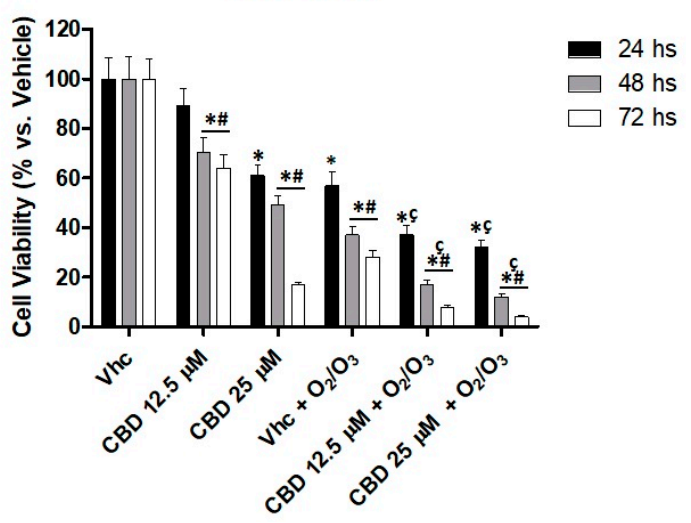

Figure 7. $\mathrm{O}_{2} / \mathrm{O}_{3}$ improved CBD cytotoxicity in PDAC cell lines. Cell viability, up to $72 \mathrm{~h}$, was determined by MTT assay. PANC- 1 and MiaPaCa- 2 cells were treated with $\mathrm{O}_{2} / \mathrm{O}_{3}$ and CBD (12.5 and $\left.25 \mu \mathrm{M}\right)$ in daily administration. Data shown are expressed as mean \pm SE of three separate experiments. ${ }^{*} p<0.05$ treated vs. vehicle, ${ }^{\#} p<0.0548,72$ h vs. 24 h, ${ }^{\varsigma} p<0.05$ vs. CBD.

Furthermore, H6c7 and NHF were daily treated with $\mathrm{CBD}$ and $\mathrm{O}_{2} / \mathrm{O}_{3}$, as performed with PANC-1 and MiaPaCa-2 cell lines, and cell viability was evaluated at $72 \mathrm{~h}$ post-treatment. The results evidenced that $\mathrm{O}_{2} / \mathrm{O}_{3}$ did not influence $\mathrm{H} 6 \mathrm{c} 7$ and NHF cell viability and did not increase the CBD-effects (Figure S4). Summarizing, $\mathrm{H6c7}$ and NHF cell lines resulted less sensitive to $\mathrm{CBD}$ and $\mathrm{O}_{2} / \mathrm{O}_{3}$ both administered alone and in combination, as described in Table 1. 
Table 1. $\mathrm{IC}_{50}$ values and percentages of viability in PANC-1, MiaPaCa-2, H6c7 and NHF cell lines with $\mathrm{CBD}$ and $\mathrm{O}_{2} / \mathrm{O}_{3}$, alone or in combination, expressed as mean $\pm \mathrm{SD}$ of three separate experiments.

\begin{tabular}{ccccc}
\hline Treatment & PANC-1 & MiaPaCa-2 & H6c7 & NHF \\
\hline CBD IC $_{50}(\mu \mathrm{M})$ & $20.3 \pm 0.4$ & $18.6 \pm 1.2$ & $28.6 \pm 0.6$ & $30.6 \pm 1.1$ \\
\hline $\begin{array}{c}\text { Vhc } \mathrm{O}_{2} / \mathrm{O}_{3} \\
\text { \% of viability }(72 \mathrm{~h})\end{array}$ & $40.2 \pm 3.8$ & $28.1 \pm 2.7$ & $92.2 \pm 8.1$ & $89.1 \pm 5.7$ \\
\hline $\begin{array}{c}\mathrm{CBD} 12.5 \mu \mathrm{M}+\mathrm{O}_{2} / \mathrm{O}_{3} \\
\% \text { of viability }(72 \mathrm{~h})\end{array}$ & $24.1 \pm 1.1$ & $8.1 \pm 0.7$ & $87.9 \pm 6.5$ & $84.5 \pm 2.6$ \\
\hline $\begin{array}{c}\mathrm{CBD} 25 \mu \mathrm{M}+\mathrm{O}_{2} / \mathrm{O}_{3} \\
\% \text { of viability }(72 \mathrm{~h})\end{array}$ & $13.1 \pm 0.4$ & $4.1 \pm 0.4$ & $50.9 \pm 4.1$ & $54.6 \pm 3.2$ \\
\hline
\end{tabular}

Moreover, cell death was examined at $24 \mathrm{~h}$ post-treatment, by Annexin V staining and PI incorporation assay and results showed that $\mathrm{O}_{2} / \mathrm{O}_{3}$ is able to induce necrotic cell death in both cell lines, and that $\mathrm{O}_{2} / \mathrm{O}_{3}-\mathrm{CBD}$ treatment increases the percentage of PI positive cells (Figure 8).

PANC-1

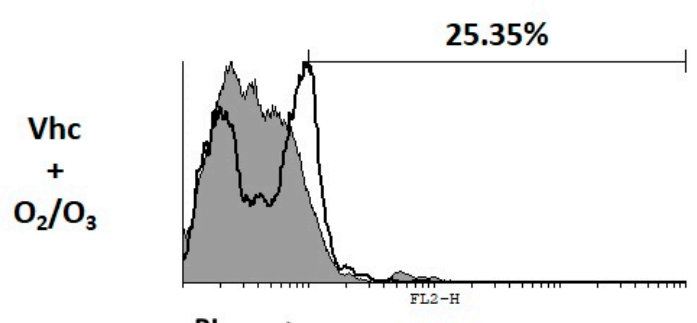

$\mathrm{PI} \longrightarrow$

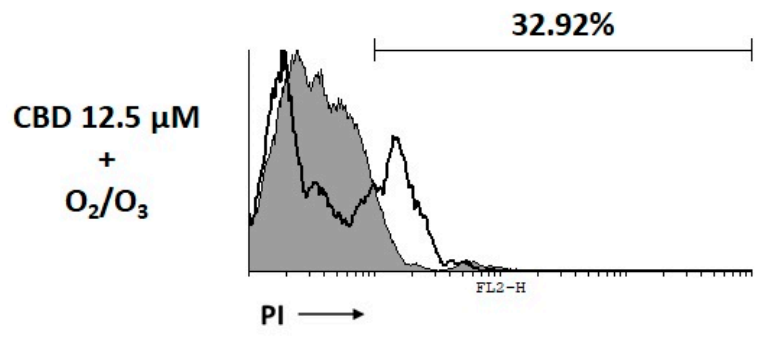

$44.46 \%$

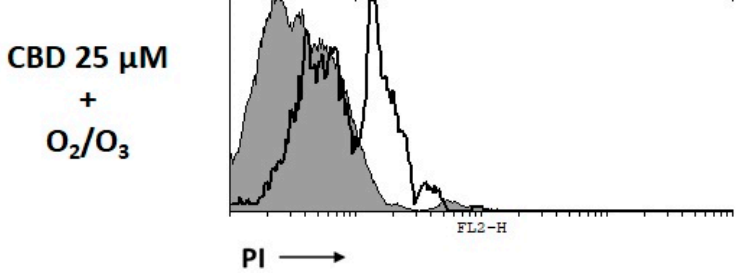

MiaPaCa-2
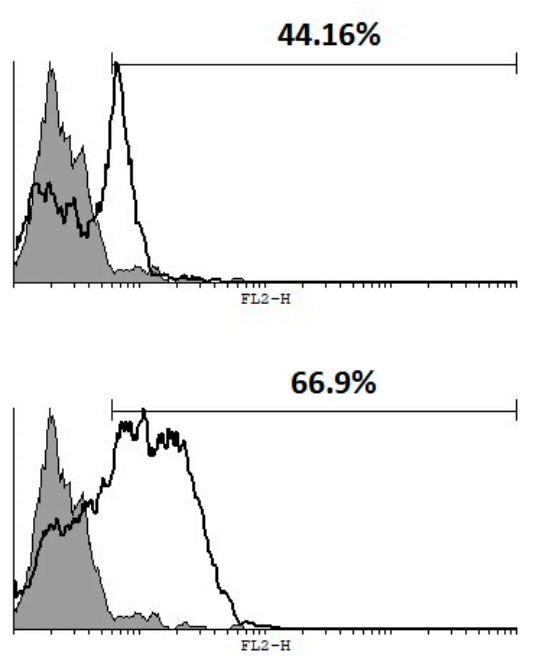

$74.3 \%$

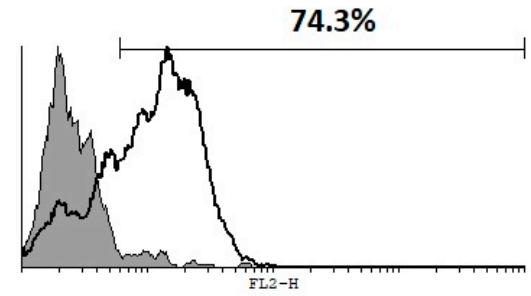

Figure 8. $\mathrm{O}_{2} / \mathrm{O}_{3}$ induced necrotic cell death in PDAC cell lines. PDAC cell lines were treated with $\mathrm{O}_{2} / \mathrm{O}_{3}$ and $\mathrm{CBD}$ for $24 \mathrm{~h}$. Flow cytometric analysis was performed by Annexin V/PI staining. Data represent the percentage of PI positive cells and are representative of one of three separate experiments.

To further evaluate the role of $\mathrm{O}_{2} / \mathrm{O}_{3}$ in modulating the effect of CBD in combination with chemotherapeutic drugs, both cell lines were treated with GEM or PTX up to $48 \mathrm{~h}$ after $\mathrm{O}_{2} / \mathrm{O}_{3}$ addition. Cell viability was calculated comparing with untreated cells in presence of $\mathrm{O}_{2} / \mathrm{O}_{3}$. The results evidenced that the combination of $\mathrm{O}_{2} / \mathrm{O}_{3}$ with $\mathrm{CBD}$ plus chemotherapeutic drugs increases the cytotoxic activity showed by $\mathrm{O}_{2} / \mathrm{O}_{3}$ alone and by $\mathrm{CBD}$ plus chemotherapeutic drugs without $\mathrm{O}_{2} / \mathrm{O}_{3}$, as shown (Figure 9). Summarising, these results indicate that the combination $\mathrm{O}_{2} / \mathrm{O}_{3}$ plus $\mathrm{CBD}$ improves the cytotoxic activity of chemotherapeutic drugs. 
PANC-1

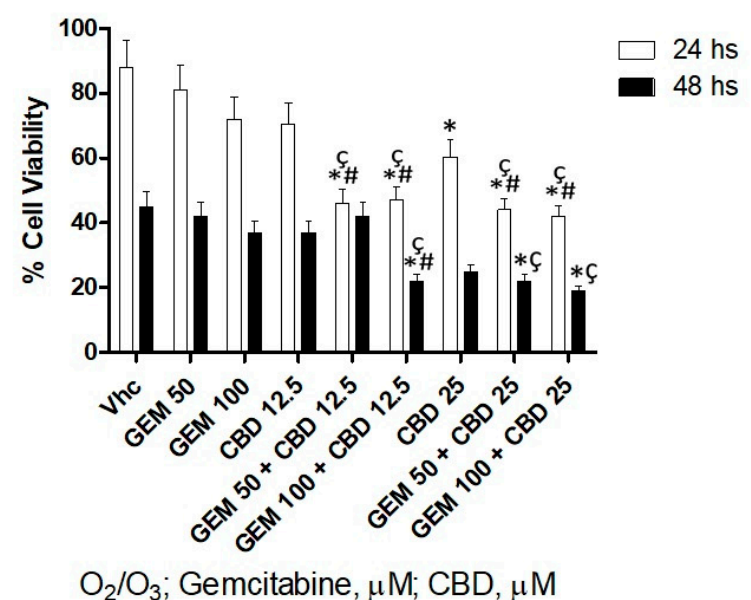

MiaPaCa-2

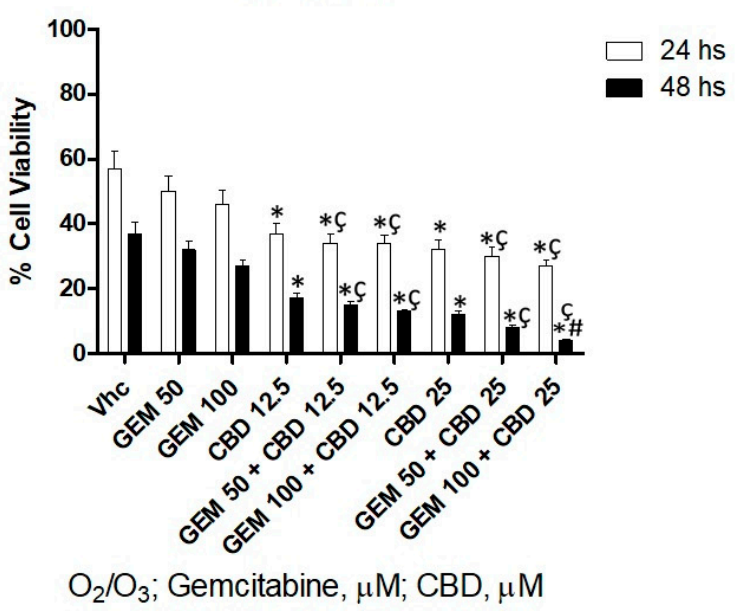

PANC-1

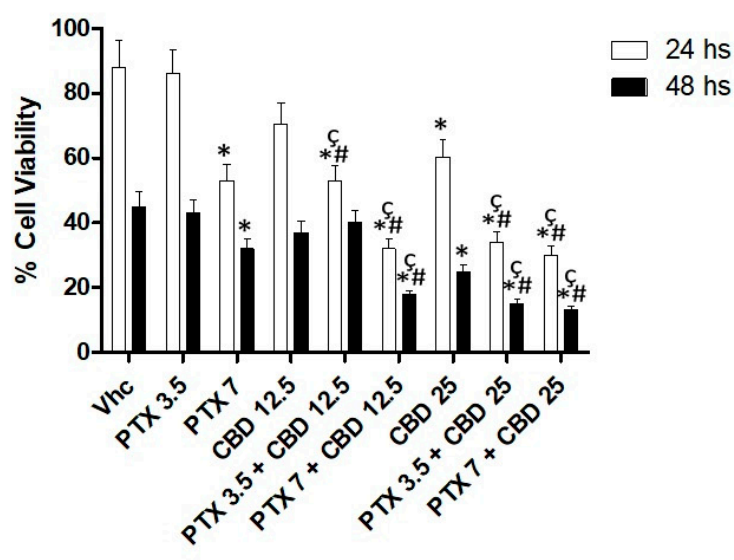

$\mathrm{O}_{2} / \mathrm{O}_{3} ;$ Paclitaxel, $\mu \mathrm{M} ; \mathrm{CBD}, \mu \mathrm{M}$

MiaPaCa-2

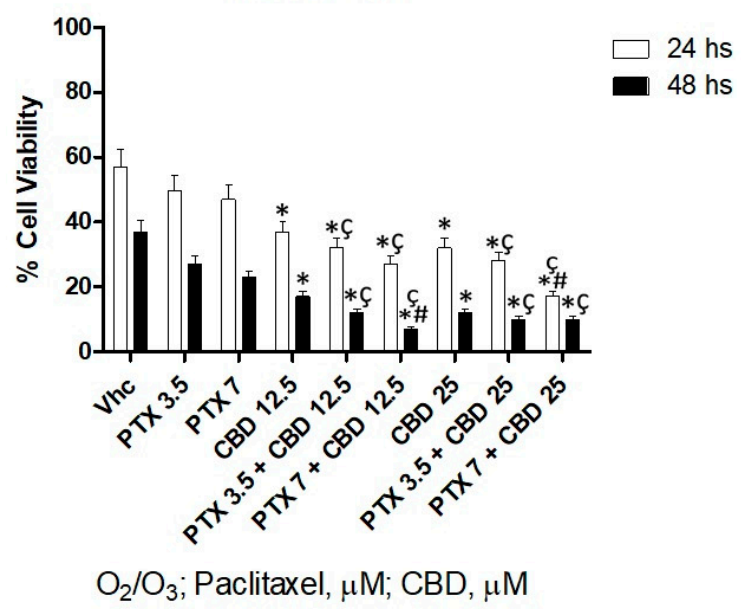

Figure 9. Addition of $\mathrm{O}_{2} / \mathrm{O}_{3}$ improves cytotoxic effect of $\mathrm{CBD}$ and chemotherapeutic drugs. Cell viability was determined in PDAC cell lines by MTT assay, and the percentage of cell viability was calculated compared with $\mathrm{O}_{2} / \mathrm{O}_{3}$ alone. Vhc showed in the graph is $\mathrm{O}_{2} / \mathrm{O}_{3}$ alone. $\mathrm{O}_{2} / \mathrm{O}_{3}$ conditioned cells were treated for 24 and $48 \mathrm{~h}$ with CBD, alone and in combination with different doses of GEM and PTX. Data shown are expressed as mean $\pm \mathrm{SE}$ of three separate experiments. ${ }^{*} p<0.05 \mathrm{vs}$. Vhc ${ }^{\#} p<0.05 \mathrm{vs}$. CBD alone, $\varsigma p<0.05$ vs. chemotherapeutic drug alone.

\subsection{Gene Modulation by $\mathrm{CBD}$ and $\mathrm{O}_{2} / \mathrm{O}_{3}$ Treatments in PDAC Cell Lines}

To elucidate the molecular events induced by $\mathrm{CBD}$ and $\mathrm{O}_{2} / \mathrm{O}_{3}$ treatment, 92 genes involved in PDAC progression and aggressiveness were evaluated by Taqman Array. Both cell lines were treated with $\mathrm{CBD}, \mathrm{O}_{2} / \mathrm{O}_{3}$, and with $\mathrm{CBD}$ plus $\mathrm{O}_{2} / \mathrm{O}_{3}$, and the molecular pathways of PDAC associated gene were evaluated. As shown, different pathways involved in PDAC carcinogenesis were modulated by $\mathrm{CBD}, \mathrm{O}_{2} / \mathrm{O}_{3}$, and by their combination, suggesting that both treatments influence common but also specific pathways. Regarding the effect in regulating genes involved in cell cycle progression, the major effects of CBD, after $24 \mathrm{~h}$ of treatment, was in down-regulation of Cyclin A2 (CCNA2) (Figure 10A, Figure S5A). The effect of $\mathrm{O}_{2} / \mathrm{O}_{3}$ should be considered as very effective in regulating cell cycle since all the Cyclins (CCNs), Cyclin Dependent Kinases (CDKs) and E2Fs (E2F1, E2F3) analysed were down-regulated after $24 \mathrm{~h}$ of treatments, while the $C D K N 2 A$ expression was up-regulated, compared to vehicle-treated cells (Figure 10B, Figure S5B). Moreover, the co-treatments with $\mathrm{O}_{2} / \mathrm{O}_{3}$ and $\mathrm{CBD}$, confirmed the effect of $\mathrm{O}_{2} / \mathrm{O}_{3}$ and, additionally, further up-regulated $C D K N 2 A$ with respect to $\mathrm{O}_{2} / \mathrm{O}_{3}$-treated cells (Figure 10B, Figure S5B). To support the modulation of cell cycle gene pathways 
by $\mathrm{CBD}$ and $\mathrm{O}_{2} / \mathrm{O}_{3}$, PI staining and cell cycle analysis was performed. As reported, $\mathrm{CBD}$ and $\mathrm{O}_{2} / \mathrm{O}_{3}$ alone slightly increased G2/M phase while the combination of both induced also a slight rise in Sub-G1 phase, in both cell lines (Figure S6).

A

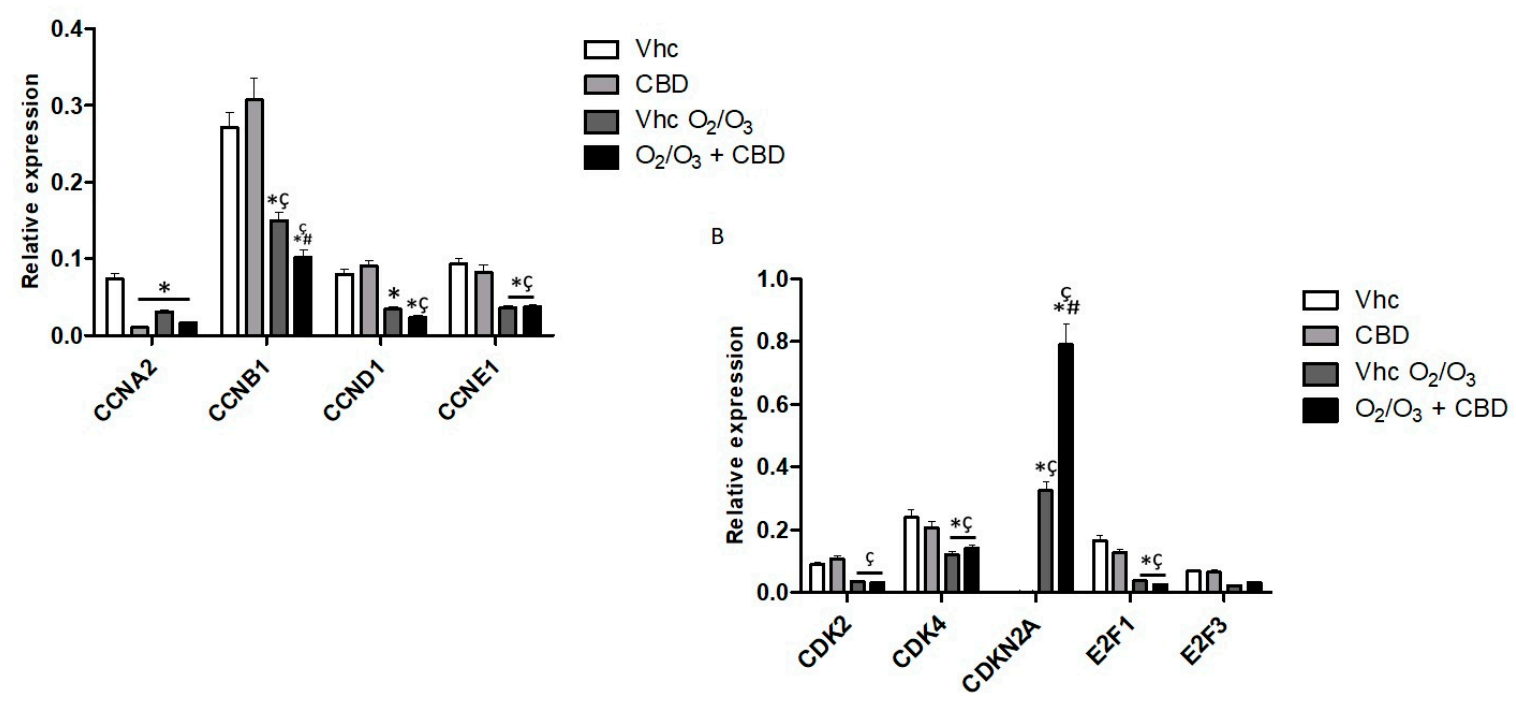

Figure 10. Modulation of cell cycle pathways in PANC-1 cell line. (A) CCNA2, CCNB1, and CCND1, CCNE1 mRNA expression and (B) CDK2, CDK4, CDKN2A, E2F1, and E2F3 mRNA expression was evaluated by qRT-PCR in the PANC-1 cell line, treated with CBD in the presence and absence of $\mathrm{O}_{2} / \mathrm{O}_{3}$. Target mRNA levels were normalized for GAPDH expression. Data are expressed as fold mean $\pm \mathrm{SE}$. ${ }^{*} p<0.05$ vs. Vhc, ${ }^{\#, *} p<0.05$ vs. Vhc $\mathrm{O}_{2} / \mathrm{O}_{3},{ }^{\varsigma} p<0.05$ vs. CBD.

Summarising, these data suggest that the co-treatment with $\mathrm{O}_{2} / \mathrm{O}_{3}$ and $\mathrm{CBD}$ was efficient in reducing cell cycle progression in PDAC cell lines, regulating several markers associated with cancer cell proliferation.

Moreover, we found that CBD significantly reduced ETS Like-1 protein Elk-1 (ELK1), Erb-B2 Receptor Tyrosine Kinase 2 (ERBB2), Mitogen-activated Protein Kinase Kinase 1 (MAP2K1), and RAF-1, while no effects were observed in Ras-pathways inhibitors, compared to vehicle treated cells (Figure 11, Figure S7). Comparing $\mathrm{O}_{2} / \mathrm{O}_{3}$ treatments with vehicle-treated cells, we found that all the Ras-associated pathways genes were down-regulated, while no effect was observed for Rac Family Small GTPase 2 (RAC2) (Figure 11, Figure S7). The combination with CBD induced a total inhibition of $B R A F$ gene expression and strongly increased $M A P 2 K 1, M A P 2 K 2$, and $E R B B 2$ gene levels compared with $\mathrm{O}_{2} / \mathrm{O}_{3}$ alone. Furthermore, no significant additional effects on the others Ras-associated genes were observed (Figure 11, Figure S7). 
A

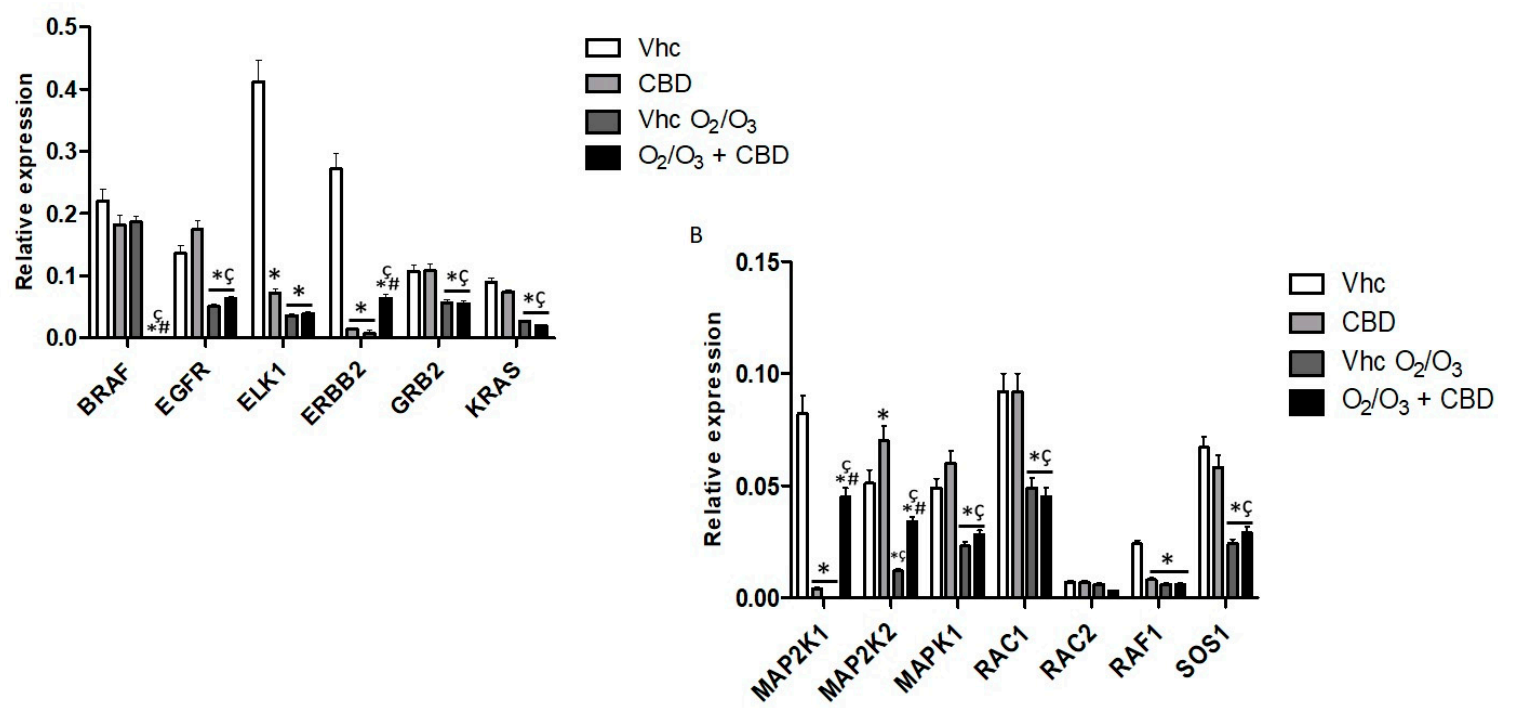

Figure 11. Modulation of Ras pathways in PANC-1 cell line. (A) BRAF, EGFR, ELK1, ERBB2, GRB2, and KRAS mRNA expression and (B) MAP2K1, MAP2K2, MAPK1, RAC1, RAC2, RAF1, and SOS1 mRNA expression was evaluated by qRT-PCR in the PANC-1 cell line, treated with CBD in the presence and absence of $\mathrm{O}_{2} / \mathrm{O}_{3}$. Target mRNA levels were normalized for GAPDH expression. Data are expressed as fold mean \pm SE. ${ }^{*} p<0.05$ vs. Vhc, ${ }^{\#, *} p<0.05$ vs. Vhc $\mathrm{O}_{2} / \mathrm{O}_{3},{ }^{\text {c }} p<0.05$ vs. CBD.

Thanks to Taqman Array we also detected that CBD significantly increases the TP53 gene, which is associated with DNA repair (Figure 12, Figure S8). $\mathrm{O}_{2} / \mathrm{O}_{3}$ treatment was effective in increasing BRCA2 and TP53 gene expression with respect to vehicle-treated cells (Figure 12, Figure S8). However, the combination with CBD reduced BRCA2 and TP53 gene expression, restoring the expression of untreated cells (Figure 12, Figure S8).

\section{DNA repair}

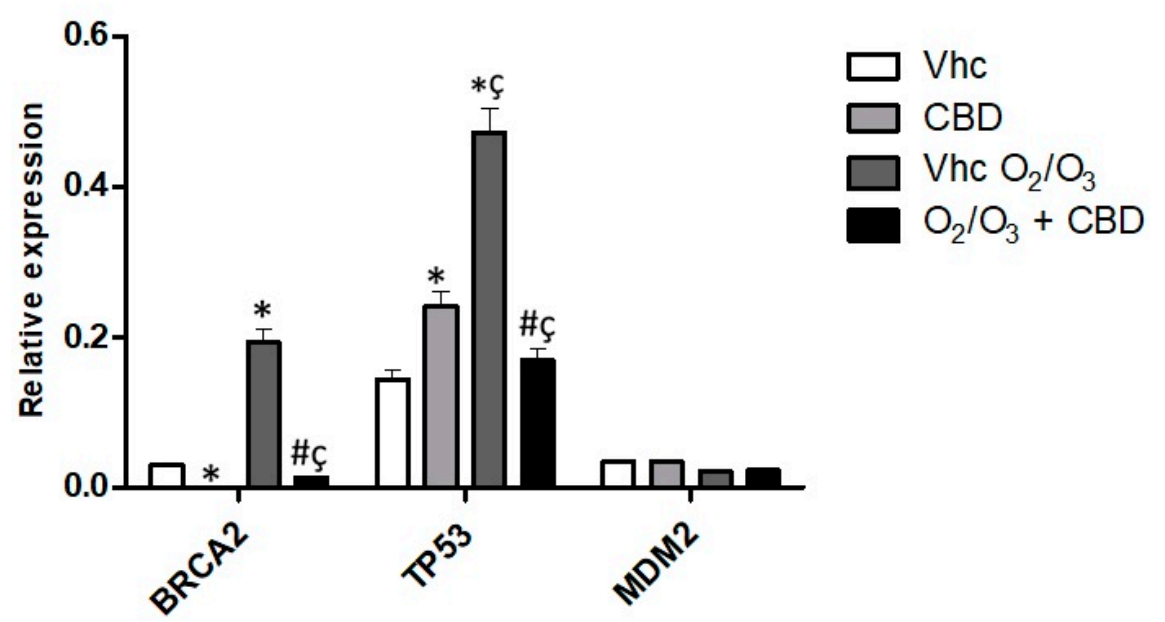

Figure 12. Modulation of DNA repair pathways in PANC-1 cell line. BRCA2, TP53, and MDM2 mRNA expression was evaluated by qRT-PCR in the PANC-1 cell line, treated with CBD in the presence and absence of $\mathrm{O}_{2} / \mathrm{O}_{3}$. Target mRNA levels were normalized for GAPDH expression. Data are expressed as fold mean \pm SE. ${ }^{*} p<0.05$ vs. Vhc, ${ }^{\#, *} p<0.05$ vs. Vhc $\mathrm{O}_{2} / \mathrm{O}_{3},{ }^{\varsigma} p<0.05$ vs. CBD.

Regarding the Nf-kB pathway, CBD significantly increased RELB (Figure 13, Figure S7). $\mathrm{O}_{2} / \mathrm{O}_{3}$ treatment was effective in reducing $N F-k B 2, R E L$ and Ras Homolog Family Member A (RHOA) gene 
expression with respect to vehicle-treated cells (Figure 13, Figure S9). The combination with CBD did not produce additional effects, except a further reduction in RHOA gene level. (Figure 13, Figure S9).

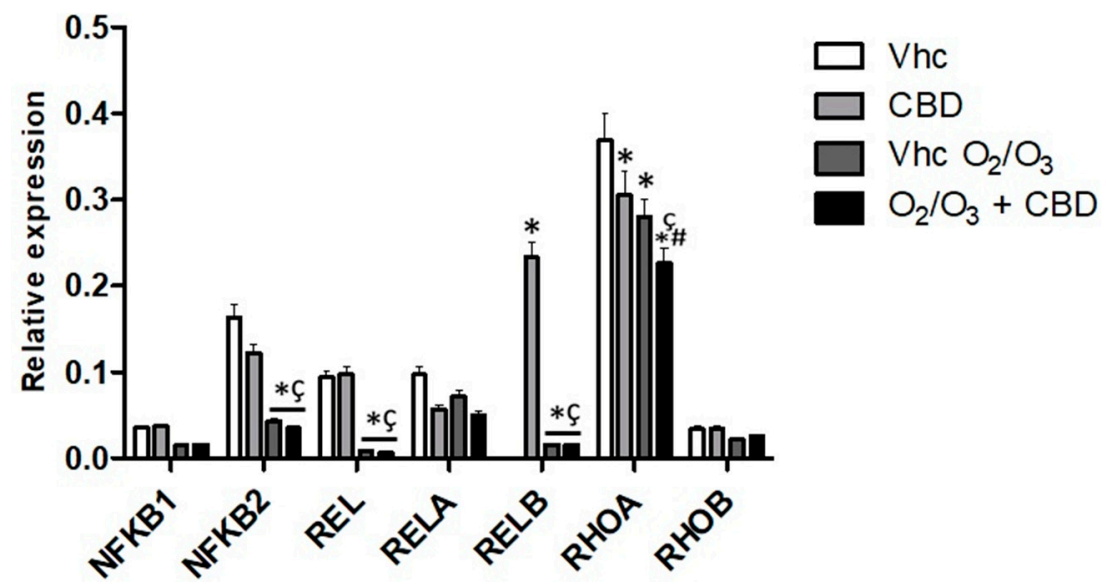

Figure 13. Modulation of NF-kB pathways in PANC-1 cell line. NFKB1, NFKB2, REL, RELA, RELB, $R H O A$, and $R H O B$ mRNA expression was evaluated by qRT-PCR in the PANC-1 cell line, treated with $C B D$ in the presence and absence of $\mathrm{O}_{2} / \mathrm{O}_{3}$. Target mRNA levels were normalized for GAPDH expression. Data are expressed as fold mean \pm SE. ${ }^{*} p<0.05$ vs. Vhc, ${ }^{\#, *} p<0.05$ vs. $\mathrm{Vhc}_{2} / \mathrm{O}_{3}$, § $p<0.05$ vs. CBD.

Regarding Phosphatidylinositol 3-kinase/Protein kinase B (PI3K/AKT) pathway, CBD did not significantly modulate the expression of the main genes. Indeed, it induced a slight increase in PIK3CD and only PIK3CB, PIK3R1 and PIK3R2 were reduced. (Figure 14, Figure $\mathrm{S} 10 \mathrm{~A}$ ). $\mathrm{O}_{2} / \mathrm{O}_{3}$ treatments reduced the expression of all analyzed genes compared with vehicle-treated cells (Figure 14B, Figure S10B), and the combination with $\mathrm{CBD}$ maintained the effect of $\mathrm{O}_{2} / \mathrm{O}_{3}$ (Figure 14, Figure S10).

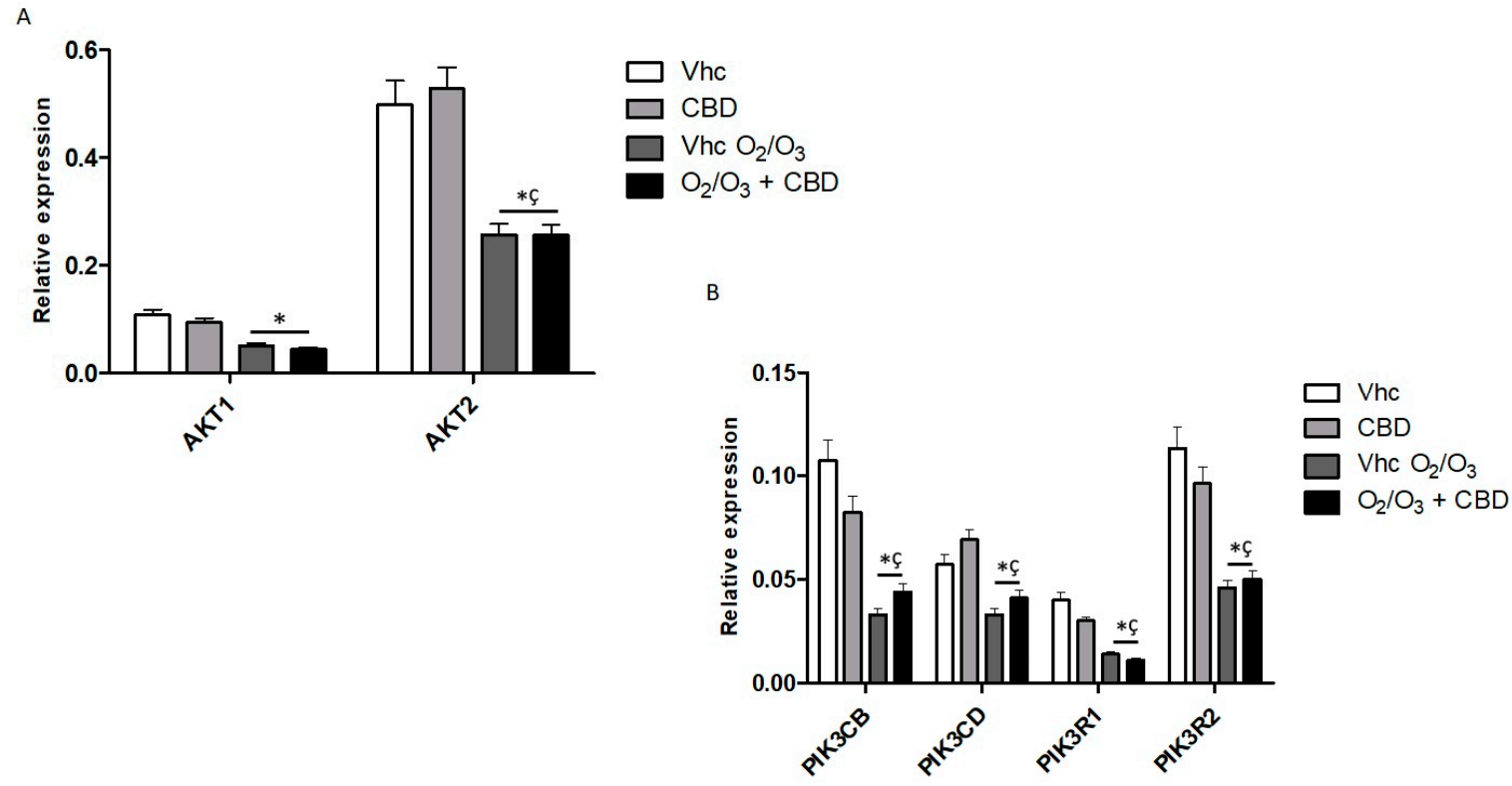

Figure 14. Modulation of PI3K/AKT pathway in PANC-1 cell line. (A) AKT1 and AKT2 mRNA expression and (B) PIK3CB, PIK3CD, PIK3R1 and PIK3R2 mRNA expression was evaluated by qRT-PCR in PANC-1 cell line, treated with CBD in presence and absence of $\mathrm{O}_{2} / \mathrm{O}_{3}$. Target mRNA levels were normalized for GAPDH expression. Data are expressed as fold mean $\pm \mathrm{SE}$. ${ }^{*} p<0.05 \mathrm{vs}$. Vhc, ${ }^{\#, *} p<$ 0.05 vs. Vhc $\mathrm{O}_{2} / \mathrm{O}_{3},{ }^{\varsigma} p<0.05$ vs. CBD. 


\section{Discussion}

PDAC patients present for $80-90 \%$ non-resectable stage cancer or distal metastasis, so systemic chemotherapy is applied as first-line treatment $[10,35]$. This therapy includes GEM, PTX, and nucleoside analogues [36] in monotherapy or in combination with radiotherapy or by a poly-chemotherapeutic regiment [37]. However, so far treatment efficacy in PDAC is considered limited. The interest associated with cannabinoids administration is related to their palliative effects useful for the treatment of cancer pain, but also for their activity as anticancer compounds able to induce inhibition of cancer cell growth and increasing cancer cell death. CBD anticancer effects, recently reviewed, were investigated in in vitro and in vivo models of glioma, leukaemia, breast, lung, thyroid, colon carcinoma, myeloma, and melanoma [25]. CBD activities are mediated through the binding to different receptors (CB1, CB2, and Gpr55 receptors), and some members of TRP channels family (as TRPV1-2-3-4, TRPM8 and TRPA1), but also by a receptor-independent mechanism [38,39]. We firstly profiled CBD-ligand receptors expression, evidencing low levels of CB1 in both cell lines, while CB2 receptor was more expressed in PANC-1 than in MiaPaCa-2. Previously, CB1 and CB2 expression was evaluated in four human pancreatic cancer cell lines and biopsies compared to normal pancreatic biopsies. Data showed different $\mathrm{CB} 1$ and $\mathrm{CB} 2$ expression levels in pancreatic cancer cell lines, compared to normal pancreatic tissues [40]. Moreover, according to our results, mRNA levels of CB1 and CB2 showed equal quantities of CB1 receptor in PANC-1 and MiaPaCa-2 cell lines and confirmed higher levels of CB2 receptor in PANC-1 respect to MiaPaCa-2 [41].

Up to now, the role of CBD in inducing anticancer effect in pancreatic cancer has not been well characterized. However, it was found that $\Delta 9$-tetrahydrocannabinol (THC) decreased PANC- 1 and MiaPaCa-2 cell viability and induced apoptotic cell death both in vitro and in vivo [40]. Moreover, CBD through a GPR55 receptor antagonism was evidenced to reduce cell growth, cell cycle progression, and Mitogen-Activated Protein Kinase 1 (MAPK) signaling in different PDAC cell lines and the combination of CBD and GEM, was more effective compared with either treatment alone [33,34]. GEM and PTX are chemotherapeutic drugs normally used for pancreatic cancer therapy. In our study the combined treatment with CBD/GEM and CBD/PTX was able to reduce cancer cells viability, and showed an increased effect underlined using different doses of $C B D$ and chemotherapeutic drugs. Our study also showed CBD's ability to reduce PANC-1 and MiaPaCa- 2 migration and similar evidence was found in other cancer cell lines [26,42].

Regarding $\mathrm{O}_{2} / \mathrm{O}_{3}$ therapy, evidence has been provided of the anti-cancer effect of local administration of ozonated water treatment in vitro and in vivo, in a mouse model of rectal cancer. The local treatment induced damages only in the tumor tissues by inducing necrosis without affecting normal tissues [43]. Moreover, the inhibitory effect of $\mathrm{O}_{2} / \mathrm{O}_{3}$ treatment in two human neuroblastoma cell lines was analyzed [24]. In this study, it was demonstrated that $\mathrm{O}_{2} / \mathrm{O}_{3}$ treatment was able to reduce cell growth and to arrest cell cycle at G2 phase, by inhibiting the expression and localization of cyclin $\mathrm{B} 1 / \mathrm{cdk} 1$ in neuroblastoma cell lines. Additionally, it was also evidenced that $\mathrm{O}_{2} / \mathrm{O}_{3}$ improved the responsiveness to Cisplatin, Etoposide, and GEM [24]. These results support our evidence in pancreatic cell lines in which $\mathrm{O}_{2} / \mathrm{O}_{3}$ administration strongly reduced PDAC cells viability, inducing necrotic cell death, and it was shown that $\mathrm{O}_{2} / \mathrm{O}_{3}$ treatment is able to act synergistically with the common chemotherapeutic drugs used in pancreatic cancer management, PTX and GEM. Thus, supported by these results, we focused our attention on $\mathrm{CBD}$ and $\mathrm{O}_{2} / \mathrm{O}_{3}$ combination, since no data were available about this potential co-administration. We found that CBD plus $\mathrm{O}_{2} / \mathrm{O}_{3}$ enhanced the effect of both single treatments in reducing cell viability and increasing cell death, with effects observed just after $24 \mathrm{~h}$ of co-treatments, suggesting that the early effect was predominantly attributable to $\mathrm{O}_{2} / \mathrm{O}_{3}$. CBD was previously reported to have less cytotoxicity in non-tumoral cells [44]. The process that regulates the lower effects of $\mathrm{O}_{2} / \mathrm{O}_{3}$ in non-tumoral cells is not well investigated. However, different research papers evidenced that $\mathrm{O}_{2} / \mathrm{O}_{3}$ has a protective effect in normal cells, while it is toxic for cancer cells $[45,46]$.

Different whole-exome sequencing studies on PDAC elucidated the major mutations and somatic copy number alterations including KRAS, TP53, SMAD4, CDKN2A, and damage repair genes such as 
$B R C A 1, B R C A 2$, giving rise to high cell proliferation and migration, reduction of cell death and genomic instability [47-49]. Since very little information relating to the molecular pathways involved in CBD and $\mathrm{O}_{2} / \mathrm{O}_{3}$ effects are available, we investigated which genes could be modulated in PDAC cell lines, by analyzing 92 PDAC associated genes. Regarding cell cycle and proliferation pathways, we found that CBD reduced the expression of $C C N A 2 . \mathrm{O}_{2} / \mathrm{O}_{3}$ strongly inhibited most of the genes that stimulate cell cycle-all of the CCNs, $C D K s$, and E2Fs (E2F1, E2F3)-while CDKN2A expression was up-regulated. In addition, the co-treatments with $\mathrm{O}_{2} / \mathrm{O}_{3}$ and $\mathrm{CBD}$ further up-regulated $C D K N 2 A$ with respect to $\mathrm{O}_{2} / \mathrm{O}_{3}$-treated cells. Similarly, $\mathrm{CBD}$ was found to inhibit Ras-associated genes such as ERBB2, RAF-1, $E L K 1, M A P 2 K 1$ and these effects were maintained in co-treatments with $\mathrm{O}_{2} / \mathrm{O}_{3}$ for $E L K 1$ and $R A F-1$, evidencing another potential mechanism to reduce PDAC gene profile. These data suggested that CBD and $\mathrm{O}_{2} / \mathrm{O}_{3}$ should have an important role in dis-regulating the Ras pathways and its downstream CDKs signaling, and that could have potential therapeutic implications, since this pathway is correlated with various oncogenic signals, such as proliferation, chemoresistance, and migration in PDAC, as recently reviewed [50]. In addition, it should be taken into consideration that pre-clinical data revealed pharmacological inhibition of Ras pathways and MAPK signaling results in compensatory activation of PI3K/Akt signaling and vice versa, both of them necessary for PDAC progression [51,52] and that independent of Ras pathways, PI3K/Akt is often elevated in PDAC and correlated to tumor cell survival $[53,54]$. Herein, we also evidenced that $\mathrm{CBD}$ and $\mathrm{O}_{2} / \mathrm{O}_{3}$, as single treatment or in combination, are able to reduce the expression of different genes of the PI3K pathway. PDAC, as above described, is also characterized by the acquisition of an anti-apoptotic phenotype, partially by inhibition of p53 and over-expression of anti-apoptotic proteins, which correlate with short survival and overall survival, particularly in Bcl-2 positive cases [55,56], and mutation in genes related to DNA damage response, such as $B R C A 1 / 2[54,57]$. Herein, we showed that $C B D$ alone increased $p 53$ and reduced $B R C A 2$ gene expression. Moreover, the combination with $\mathrm{O}_{2} / \mathrm{O}_{3}$ restored the expression of untreated cells. In different cancer models, it was demonstrated that BRCA2 leads to accumulation of DNA breaks, and results in activation of p53, which promotes cell cycle arrest and activation of cell death [58,59]. Moreover, in cancer, BRCA2 inactivation leads to pro-inflammatory cytokines production, that is a determinant for cancer cell survival [60], and several studies have investigated the expression profile of various cytokines in patients with PDAC and Nuclear Factor kB (NF-kB) activation pathways that have also been shown to be involved in pancreatic cancer development [61-63]. Moreover, inhibiting $\mathrm{NF}-\mathrm{KB}$ and its downstream targets, lead to the inhibition of proliferation, angiogenesis, and invasion as reported in the PDAC mouse model [64]. Herein, the effects of $C B D$ and $\mathrm{O}_{2} / \mathrm{O}_{3}$ on Nf-kB pathways were analyzed, and the results evidenced that $\mathrm{O}_{2} / \mathrm{O}_{3}$ alone and in combination with $\mathrm{CBD}$ was able to reduce NF-kB-related genes supporting their role in reducing inflammation and potentially cellular migration.

Summarizing, our results showed that $\mathrm{CBD}$ and $\mathrm{O}_{2} / \mathrm{O}_{3}$ were both able to induce significant changes in the expression profile of genes strongly involved in PDAC leading to the inhibition of cell viability, invasion, and increasing cell death. Moreover, $\mathrm{CBD}$ and $\mathrm{O}_{2} / \mathrm{O}_{3}$ was found to increase the anti-tumoral effects of Gemcitabine and Paclitaxel, suggesting that these combinations could have significant potential as an effective therapy for pancreatic cancer that can enhance the effect of chemotherapy and overcome chemoresistance.

\section{Materials and Methods}

\subsection{Cell Lines}

Human pancreatic ductal adenocarcinoma (PANC-1 and MiaPaCa-2) cell lines were purchased by Sigma Aldrich (Milan, Italy) and cultured in DMEM high glucose medium (EuroClone, Milan, Italy) supplemented with $10 \%$ of fetal bovine serum (FBS), $2 \mathrm{mM} \mathrm{L}$-glutamine, $100 \mathrm{IU} / \mathrm{mL}$ penicillin, $100 \mathrm{mg}$ streptomycin and $1 \mathrm{mM}$ sodium pyruvate. Human Pancreatic Duct Epithelial H6c7 cell line was purchased by Kerafast (Boston, MA, USA) and cultured in Keratinocyte serum free medium, supplemented with epidermal growth factor and bovine pituitary extract. Normal Human Fibroblasts 
NHF cell line was purchased by IFOM (Rome, Italy) and cultured in DMEM supplemented with 10\% of fetal bovine serum (FBS), $2 \mathrm{mM}$ L-glutamine, $100 \mathrm{IU} / \mathrm{mL}$ penicillin, $100 \mathrm{mg}$ streptomycin and $1 \mathrm{mM}$ sodium pyruvate. Cell lines were maintained at $37^{\circ} \mathrm{C}$ with $5 \% \mathrm{CO}_{2}$ and $95 \%$ of humidity.

\subsection{RNA Isolation, Reverse Transcription and Quantitative Real-Time PCR and TaqMan Array}

Briefly, total RNA from untreated or $\mathrm{CBD}$ and $\mathrm{O}_{2} / \mathrm{O}_{3}$ treated cell lines was extracted using Rneasy Mini kit (Qiagen, Milan, Italy). One microgram of total RNA from each sample was subjected to reverse transcription in a total volume of $20 \mu \mathrm{L}$ using the High-Capacity cDNA Archive Kit (Applied Biosystem, Foster City, PA, USA) according to the instructions. cDNAs were analyzed by qRT-PCR performed using an IQ5 Multicolor Real time PCR Detection system. Quantitative real-time polymerase chain reactions (qRT-PCR) were performed with QuantiTect Primer Assays (Qiagen) for Human Cannabinoid receptor 1 (CNR1, CB1), Human Cannabinoid receptor 2 (CNR2, CB2) and TRP (TRPV1, TRPV2, TRPV3, TRPV4, TRPM8, TRPA1), according to manufacturer's protocol. Measurement of $G A P D H$ levels were used to normalize mRNA contents and target gene levels were calculated by $2^{-\Delta \Delta \mathrm{Ct}}$ method. The TaqMan ${ }^{\circledR}$ Array Human Pancreatic Adenocarcinoma 96-well Plate, containing 92 assays to pancreatic adenocarcinoma associated genes and 4 assays to candidate endogenous control genes, was purchased (Thermo Fisher, Grand Island, NY, USA) and used to evaluate the effects of the treatments in modulating PDAC-related genes. Measurement of two housekeeping genes (GAPDH; HPRT1; GUSB) on the samples was used to normalize mRNA content. The gene expression levels of treated cell lines were expressed as relative fold compared with untreated or vehicle-treated cells [65].

$$
\text { ratio }=\frac{\left(E_{\text {target }}\right)^{\Delta C P_{\text {target }}(\text { control-sample })}}{\left(E_{\text {ref }}\right)^{\Delta C P_{\text {ref }}(\text { control-sample })}}
$$

\subsection{Western Blot Analysis}

Lysates of PANC-1 and MiaPaCa-2 cell lines untreated or daily treated with CBD for $48 \mathrm{~h}$, were obtained with lysis buffer (composed by TRIS 1M pH 7.4, NaCl 1M, EGTA $10 \mathrm{mM}, \mathrm{NaF} 100 \mathrm{mM}$, Deoxycholate 2\%, EDTA $100 \mathrm{mM}$, TritonX-100 10\%, Glycerol, SDS 10\%, $\mathrm{Na}_{2} \mathrm{P}_{2} \mathrm{O}_{7} 1 \mathrm{M}, \mathrm{Na}_{3} \mathrm{VO}_{4}$ $100 \mathrm{mM}$, PMSF $100 \mathrm{mM}$, Cocktail of enzyme inhibitors and $\mathrm{H}_{2} \mathrm{O}$ ). Lysates were separated on a SDS polyacrylamide gel, transferred onto Hybond-C extra membranes (GE Healthcare, Chicago, IL, USA), blocked with $5 \%$ low-fat dry milk in phosphate-buffered saline $0.1 \%$ Tween 20 overnight at $4{ }^{\circ} \mathrm{C}$, immunoblotted with mouse anti-CB1 (1:500, Santa Cruz Biotechnology, Heidelberg, Germany), rabbit anti-CB2 (1:200, Cayman Chemical, Ellsworth, MI, USA), mouse anti-TRPV1 (1:200, Santa Cruz Biotechnology), mouse anti-TRPV2 (1:200, Santa Cruz Biotechnology), rabbit anti-TRPV3 $(0.5 \mu \mathrm{g} / \mathrm{mL}$, Boster Biological Technology, Pleasanton, CA, USA), rabbit anti-TRPV4 (1:500, Assay Biotechnology Company, Fremont, CA, USA), goat anti-TRPA1 (1:300, Santa Cruz Biotechnology), rabbit anti-TRPM8 $(0.5 \mu \mathrm{g} / \mathrm{mL}$, Boster Biological Technology), mouse anti-glyceraldehydes-3-phosphate dehydrogenase (GAPDH, 1:3000, OriGene, Rockville, MD, USA), and rabbit anti-caspase-3 (1:1000, Cell Signaling, Danvers, MA, USA) Abs overnight or $1 \mathrm{~h}$ according to manufacturer's protocol and then incubated with their respective HRP-cojugated anti-rabbit, anti-mouse (1:2000, Cell Signaling, Danvers, MA, USA) or anti-goat (1:1000, Santa Cruz Biotechnology) Abs for $1 \mathrm{~h}$. Peroxidase activity was visualized with the LiteAblot ${ }^{\circledR}$ PLUS or TURBO (EuroClone, Milan, Italy) kit and densitometric analysis was carried out by a Chemidoc using the Quantity One software version 4.6 (Bio-Rad, Milan, Italy). All experiments were repeated three times.

\subsection{Reagents}

Pharmaceutical grade Cannabidiol (CBD) crystals were purchased (Pharmacy S. Albano, Torino, Italy). CBD crystals were solubilized in ethanol $70 \%$ at $50 \mathrm{mM}$ concentration. Paclitaxel (PTX; $6 \mathrm{mg} / \mathrm{mL}$ ) 
and Gemcitabine (GEM; $50 \mu \mathrm{M}$ ) were purchased by Sigma Aldrich and solubilized in water. All the compounds were aliquoted and stored at $-20^{\circ} \mathrm{C}$ and each aliquot was used one time.

\section{5. $\mathrm{O}_{2} / \mathrm{O}_{3}$ Treatments}

PANC-1 and MiaPaCa-2 cell lines were seeded on 96-well culture plates, or 12-well plates at a density of $3.0 \times 10^{4}$ cells $/ \mathrm{mL}$. The cells were pre-cultured in normoxia for $24 \mathrm{~h}$. Subsequently, the culture plates were exposed twice to $\mathrm{O}_{2} / \mathrm{O}_{3}$ treatments for $30 \mathrm{~min}$ in a Hypoxia Incubator Chamber (Stemcell Technology, Vancouver, BC, Canada), by injecting $\mathrm{O}_{2} / \mathrm{O}_{3}$ until chamber saturation, using a Midi Ozon Active machine (Medica s.r.l., Bologna, Italy).

After treatment, the cell plates were replaced in the incubator at normoxia condition $\left(37^{\circ} \mathrm{C}\right.$ with $5 \% \mathrm{CO}_{2}$ and $95 \%$ humidity) for $6 \mathrm{~h}$ and then, the $\mathrm{O}_{2} / \mathrm{O}_{3}$ treatment was repeated as described. After that, the cells plates were maintained in normoxia for 24 up to $72 \mathrm{~h}$, before performing the experiments.

\subsection{MTT Assay}

$3 \times 10^{4}$ cells $/ \mathrm{mL}$ were seeded in $96-$ well plates in a final volume of $100 \mu \mathrm{L} /$ well. After one day of incubation, compounds or vehicles, alone or in combination, were added and six replicates were used for each treatment and all experiments were repeated three times. In some experiments, the treatment was daily added, after washing with fresh medium. After 24 or $72 \mathrm{~h}$ cell viability was investigated by adding $0.8 \mathrm{mg} / \mathrm{mL}$ of 3-[4,5-dimethylthiazol-2-yl]-2,5 diphenyl tetrazolium bromide (MTT) (Sigma Aldrich) to the media. After $3 \mathrm{~h}$ the supernatant was removed, and the pellet of salt crystals was solubilized with $100 \mu \mathrm{L} /$ well of DMSO. The absorbance of the sample against a background control was measured at $570 \mathrm{~nm}$ using an ELISA reader microliter plate (BioTek Instruments, Winooski, VT, USA).

\subsection{Cell Cycle Analysis}

Cells were seeded into 6-well plates $\left(3 \times 10^{4}\right.$ cells $\left./ \mathrm{mL}\right)$ and treated with CBD $(12.5 \mu \mathrm{M})$, in the presence and absence of $\mathrm{O}_{2} / \mathrm{O}_{3}$, for $12 \mathrm{~h}$. Cells were fixed by adding ice-cold $70 \%$ ethanol for $1 \mathrm{~h}$ and then washed with staining buffer (PBS, 2\% FBS and 0.01\% NaN3). Next, cells were incubated with $100 \mu \mathrm{g} / \mathrm{mL}$ Ribonuclease A solution (Sigma Aldrich) for $30 \mathrm{~min}$ at $37^{\circ} \mathrm{C}$, stained with propidium iodide (PI) $20 \mu \mathrm{g} / \mathrm{mL}$ (Sigma Aldrich) at room temperature for $10 \mathrm{~min}$ and analysed on a FACScan flow cytometer using linear amplification and CellQuest software, version 3.0 (BD Biosciences, San Jose, CA, USA).

\subsection{Cell Death Assay}

Annexin V-FITC and PI staining followed by FACS analysis was used to evaluate cell death on PANC-1 and MiaPaCa- 2 cancer cell lines. Cells at a density of $3 \times 10^{4}$ cells/mL were treated with different doses of $C B D$, in the presence and absence of $\mathrm{O}_{2} / \mathrm{O}_{3}$, for 24 up to $48 \mathrm{~h}$. After treatment, cells were stained with $5 \mu \mathrm{L}$ of Annexin V-FITC or with $20 \mu \mathrm{g} / \mathrm{mL}$ PI for $10 \mathrm{~min}$ at room temperature and then washed with binding buffer (10 $\mathrm{mM} \mathrm{N}$-(2-Hydroxyethyl)piperazine-N0-2-ethanesulfonic acid [HEPES]/sodium hydroxide, $\mathrm{pH} 7.4,140 \mu \mathrm{M} \mathrm{NaCl}, 2.5 \mu \mathrm{M} \mathrm{CaCl}_{2}$ ). The percentage of positive cells determined over 10,000 events was analysed with FACScan flow cytometer using the CellQuest software. All experiments were repeated three times.

\subsection{Alkaline Comet Assay}

Cell lines were plated in 6-well plates $\left(3 \times 10^{4}\right.$ cells $\left./ \mathrm{mL}\right)$ one day before treatment exposure. Semi-confluent cultures were daily treated for up to $48 \mathrm{~h}$ with CBD $25 \mu \mathrm{M}$ or vehicle. Cells treated with vehicle were included. All experiments were repeated three times. The comet assay was performed under alkaline conditions following the ABCAM protocol. Briefly, after exposure to treatments, the cells were resuspended in $1 \times \mathrm{PBS}$ and added to $75 \mu \mathrm{L}$ of molten $\left(37^{\circ} \mathrm{C}\right) 0.5 \%$ low-melting-point agarose gel to achieve a cell concentration of $1 \times 10^{5}$ cells $/ \mathrm{mL}$. The agarose was pipetted onto the comet slides. 
Slides were stored in the dark at $4{ }^{\circ} \mathrm{C}$ for $10 \mathrm{~min}$ before adding pre-chilled lysis buffer for $45 \mathrm{~min}$ at $4{ }^{\circ} \mathrm{C}$ in the dark. The slides were immersed in freshly prepared alkaline solution $(0.25 \mathrm{M} \mathrm{NaOH}$ containing $0.1 \mu \mathrm{M}$ EDTA, pH 12.6) for $30 \mathrm{~min}$ at the same conditions. Slides were then removed and washed twice with TBE buffer for $5 \mathrm{~min}$. Gel electrophoresis was performed at $1 \mathrm{~V} \mathrm{~cm}^{-1}$ (length of the electrophoretic chamber) for $20 \mathrm{~min}$ (running amperage 3-5 mA with the distance between the two electrodes of $25 \mathrm{~cm}$ ). The comet slides were washed with $70 \%$ ethanol for $5 \mathrm{~min}$ and air-dried for $1 \mathrm{~h}$ at room temperature. $100 \mu \mathrm{L}$ of diluted SYBR Green solution was placed onto each dried agarose circle. The slides were then read with a fluorescence microscope (Leica Microsystems, Buccinasco, Italy).

\subsection{Wound-Healing Assay}

PANC-1 and MiaPaCa-2 cells were seeded onto a 24-well plate at a density of $4 \times 10^{4} / \mathrm{mL}$ and $2.5 \times 10^{4} / \mathrm{mL}$, respectively. When cells were confluent, they were scratched using $10 \mu \mathrm{L}$ sterile pipette tips, and medium was replaced with fresh medium containing low percentage of serum to minimize cell proliferation and prevent cell detachment and treated with CBD $12.5 \mu \mathrm{M}$. Images of wounded areas were taken at $0 \mathrm{~h}$ and $48 \mathrm{~h}$. Images acquisition was carried out by a LeitzFluovert FU (Leica Microsystems) microscope. Remaining wound areas were determined using NIH Image J 1.44 software (Research Services Branch (RSB), National Institutes of Health (NIH), Bethesda, MD, USA) three separate distance measurements per well. Analyses were performed in triplicate.

\subsection{Statistical Analysis}

The data presented represent the mean with standard deviation (SD) of at least 3 independent experiments. Synergistic activity of the CBD and chemotherapeutic drugs combination was calculated by the Chou-Talalay method, which provides the theoretical basis for the combination index (CI)-isobologram equation. This method allows quantitative determination of drug interactions, where $\mathrm{CI}<1,=1$, and $>1$ indicates synergism, additive effect and antagonism, respectively. Based on these algorithms, computer software, CompuSyn 3.0.1 version (CompuSyn Software, ComboSyn, Inc., Paramus, NJ, USA, 2007) was used for automatically determining synergism and antagonism at all doses or effect levels [66]. The statistical significance was determined by Student's $t$-test and by One Way-Anova and Two Way-Anova with Bonferroni's post-test; ${ }^{*} p<0.05$.

\section{Conclusions}

In conclusion, we found that $\mathrm{CBD}$ and $\mathrm{O}_{2} / \mathrm{O}_{3}$ were both able to induce significant changes in the expression profile of genes strongly involved in PDAC, suggesting that further study on this combination could be addressed to better elucidate the role of $C B D$ and $\mathrm{O}_{2} / \mathrm{O}_{3}$ in the progression of PDAC.

Supplementary Materials: The following are available online at http://www.mdpi.com/2072-6694/12/10/2774/s1, Figure S1: CBs and TRPs expression in PDAC cell lines. Figure S2: Human Pancreatic Duct Epithelial and Human Fibroblasts cell lines were more resistant to CBD, Figure S3: Isobologram plots and CI values for combination treatments of CBD, GEM and PTX in PANC-1 and MiaPaCa- 2 cell lines, Figure S4: $\mathrm{O}_{2} / \mathrm{O}_{3}$ did not increase CBD cytotoxicity in $\mathrm{H6c7}$ and NHF cell lines, Figure S5: Modulation of cell cycle pathways in MiaPaCa-2 cell line. Figure S6: $\mathrm{O}_{2} / \mathrm{O}_{3}$, alone and in combination with CBD, reduced cell cycle progression in PANC-1 and MiaPaCa-2 cell lines. Figure S7: Modulation of Ras pathways in MiaPaCa-2 cell line, Figure S8: Modulation of DNA repair pathways in MiaPaCa-2 cell line, Figure S9: Modulation of NF-kB pathways in MiaPaCa-2 cell line, Figure S10: Modulation of PI3K/AKT pathway in MiaPaCa-2 cell line, Figure S11: Uncropped Western blot images from Figure 3 and Figure S1.

Author Contributions: Conceptualization, M.L., M.N.; investigation and data curation, M.N., O.M., L.Z., C.A. (Cristina Aguzzi); resources, A.F. (Andrea Frassineti); writing—original draft preparation, M.N.; writing-review and editing, M.d.C., A.F. (Alessandro Fanelli), C.A. (Consuelo Amantini), M.B.M., G.S.; supervision, M.N. All authors have read and agreed to the published version of the manuscript.

Funding: This work was partially supported by grants from Maria Guarino" Foundation-AMOR No Profit Association and UNICAM School Advanced Studies in Life and Health Sciences. 
Acknowledgments: M.B.M. was supported by Fondazione Umberto Veronesi (Post-doctoral Fellowship 2018, 2019 to M.B.M.). This work is dedicated to Claudio and Michele.

Conflicts of Interest: The authors declare no conflict of interest.

\section{Abbreviations}

\begin{tabular}{|c|c|}
\hline AKT & Protein kinase B \\
\hline ATM & ATM Serine/Threonine Kinase \\
\hline BRCA1/2 & Breast Cancer Type $1 / 2$ susceptibility protein \\
\hline Casp3 & Caspase 3 \\
\hline CB1 & Cannabinoid Receptor 1 \\
\hline CB2 & Cannabinoid Receptor 2 \\
\hline CBD & Cannabidiol \\
\hline CCNA2 & Cyclin A2 \\
\hline CDKN2A & Cyclin Dependent Kinase Inhibitor 2A \\
\hline CDKs & Cyclin Dependent Kinases \\
\hline EGFR & Epidermal Growth Factor Receptor \\
\hline ELK1 & ETS Like-1 protein Elk-1 \\
\hline ERBB2 & Erb-B2 Receptor Tyrosine Kinase 2 \\
\hline GEM & Gemcitabine \\
\hline GPR55 & G Protein-Coupled Receptor 55 \\
\hline GRB2 & Growth Factor Receptor Bound Protein 2 \\
\hline MAP2K1 & Mitogen-activated Protein Kinase Kinase 1 \\
\hline MAP2K2 & Mitogen-activated Protein Kinase Kinase 2 \\
\hline MAPK1 & Mitogen-Activated Protein Kinase 1 \\
\hline MDM2 & Mouse Double Minute Homolog \\
\hline MLH1 & MutL Homolog 1 gene \\
\hline Nf-kB & Nuclear Factor kB \\
\hline $\mathrm{O}_{2} / \mathrm{O}_{3}$ & Oxygen-ozone \\
\hline PC & Pancreatic Cancer \\
\hline PDAC & Pancreatic Ductal Adenocarcinoma \\
\hline PI & Propidium Iodide \\
\hline PIK3 & Phosphatidylinositol 3-kinase \\
\hline PKB & Protein kinase B \\
\hline PPAR- $\gamma$ & Peroxisome Proliferator-Activated Receptor gamma \\
\hline PTX & Paclitaxel \\
\hline RAC1 & Rac Family Small GTPase 1 \\
\hline RAC2 & Rac Family Small GTPase 2 \\
\hline RHOA & Ras Homolog Family Member A \\
\hline RHOB & Ras Homolog Family Member B \\
\hline SMAD4 & SMAD Family Member 4 \\
\hline THC & $\Delta 9$-tetrahydrocannabinol \\
\hline TRPA1 & Transient Receptor Potential Ankyrin 1 \\
\hline TRPM8 & Transient Receptor Potential Melastatin 8 \\
\hline TRPV1 & Transient Receptor Potential Vanilloid 1 \\
\hline TRPV2 & Transient Receptor Potential Vanilloid 2 \\
\hline TRPV3 & Transient Receptor Potential Vanilloid 3 \\
\hline TRPV4 & Transient Receptor Potential Vanilloid 4 \\
\hline
\end{tabular}




\section{References}

1. Amantini, C.; Morelli, M.B.; Nabissi, M.; Piva, F.; Marinelli, O.; Maggi, F.; Bianchi, F.; Bittoni, A.; Berardi, R.; Giampieri, R.; et al. Expression Profiling of Circulating Tumor Cells in Pancreatic Ductal Adenocarcinoma Patients: Biomarkers Predicting Overall Survival. Front. Oncol. 2019, 9, 874. [CrossRef]

2. Luchini, C.; Capelli, P.; Scarpa, A. Pancreatic Ductal Adenocarcinoma and Its Variants. Surg. Pathol. Clin. 2016, 9, 547-560. [CrossRef]

3. Siegel, R.L.; Miller, K.D.; Jemal, A. Cancer statistics, 2018. CA Cancer J. Clin. 2018, 68, 7-30. [CrossRef]

4. Adamska, A.; Domenichini, A.; Falasca, M. Pancreatic Ductal Adenocarcinoma: Current and Evolving Therapies. Int. J. Mol. Sci. 2017, 18, 1338. [CrossRef]

5. Ansari, D.; Tingstedt, B.; Andersson, B.; Holmquist, F.; Sturesson, C.; Williamsson, C.; Sasor, A.; Borg, D.; Bauden, M.; Andersson, R. Pancreatic cancer: Yesterday, today and tomorrow. Future Oncol. 2016, 12, 1929-1946. [CrossRef]

6. Hu, C.; Hart, S.N.; Polley, E.C.; Gnanaolivu, R.; Shimelis, H.; Lee, K.Y.; Lilyquist, J.; Na, J.; Moore, R.; Antwi, S.O.; et al. Association Between Inherited Germline Mutations in Cancer Predisposition Genes and Risk of Pancreatic Cancer. JAMA 2018, 319, 2401-2409. [CrossRef]

7. Felsenstein, M.; Hruban, R.H.; Wood, L.D. New Developments in the Molecular Mechanisms of Pancreatic Tumorigenesis. Adv. Anat. Pathol. 2018, 25, 131-142. [CrossRef] [PubMed]

8. Wolfgang, C.L.; Herman, J.M.; Laheru, D.A.; Klein, A.P.; Erdek, M.A.; Fishman, E.K.; Hruban, R.H. Recent progress in pancreatic cancer. CA Cancer J. Clin. 2013, 63, 318-348. [CrossRef] [PubMed]

9. Gillen, S.; Schuster, T.; Meyer Zum Büschenfelde, C.; Friess, H.; Kleeff, J. Preoperative/neoadjuvant therapy in pancreatic cancer: A systematic review and meta-analysis of response and resection percentages. PLoS Med. 2010, 7, e1000267. [CrossRef] [PubMed]

10. Werner, J.; Combs, S.E.; Springfeld, C.; Hartwig, W.; Hackert, T.; Büchler, M.W. Advanced-stage pancreatic cancer: Therapy options. Nat. Rev. Clin. Oncol. 2013, 10, 323-333. [CrossRef]

11. Murphy, J.E.; Wo, J.Y.; Ryan, D.P.; Clark, J.W.; Jiang, W.; Yeap, B.Y.; Drapek, L.C.; Ly, L.; Baglini, C.V.; Blaszkowsky, L.S. Total Neoadjuvant Therapy With FOLFIRINOX in Combination With Losartan Followed by Chemoradiotherapy for Locally Advanced Pancreatic Cancer: A Phase 2 Clinical Trial. JAMA Oncol. 2019, 5, 1020-1027. [CrossRef] [PubMed]

12. Brahmer, J.R.; Tykodi, S.S.; Chow, L.Q.; Hwu, W.J.; Topalian, S.L.; Hwu, P.; Drake, C.G.; Camacho, L.H.; Kauh, J.; Odunsi, K. Safety and activity of anti-PD-L1 antibody in patients with advanced cancer. N. Engl. J. Med. 2012, 366, 2455-2465. [CrossRef] [PubMed]

13. Royal, R.E.; Levy, C.; Turner, K.; Mathur, A.; Hughes, M.; Kammula, U.S.; Sherry, R.M.; Topalian, S.L.; Yang, J.C.; Lowy, I. Phase 2 trial of single agent Ipilimumab (anti-CTLA-4) for locally advanced or metastatic pancreatic adenocarcinoma. J. Immunother. 2010, 33, 828-833. [CrossRef] [PubMed]

14. Wilson, W.R.; Hay, M.P. Targeting hypoxia in cancer therapy. Nat. Rev. Cancer 2011, 11, 393-410. [CrossRef]

15. Baran, N.; Konopleva, M. Molecular Pathways: Hypoxia-Activated Prodrugs in Cancer Therapy. Clin. Cancer Res. 2017, 23, 2382-2390. [CrossRef]

16. Karakashev, S.V.; Reginato, M.J. Progress toward overcoming hypoxia-induced resistance to solid tumor therapy. Cancer Manag. Res. 2015, 7, 253-264. [CrossRef]

17. Manoochehri Khoshinani, H.; Afshar, S.; Najafi, R. Hypoxia: A Double-Edged Sword in Cancer Therapy. Cancer Investig. 2016, 34, 536-545. [CrossRef]

18. Luongo, M.; Brigida, A.L.; Mascolo, L.; Gaudino, G. Possible Therapeutic Effects of Ozone Mixture on Hypoxia in Tumor Development. Anticancer Res. 2017, 37, 425-435. [CrossRef]

19. Bocci, V.A. Scientific and medical aspects of ozone therapy. State of the art. Arch. Med. Res. 2006, 37, 425-435. [CrossRef]

20. Fuccio, C.; Luongo, C.; Capodanno, P.; Giordano, C.; Scafuro, M.A.; Siniscalco, D.; Lettieri, B.; Rossi, F.; Maione, S.; Berrino, L. A single subcutaneous injection of ozone prevents allodynia and decreases the over-expression of pro-inflammatory caspases in the orbito-frontal cortex of neuropathic mice. Eur. J. Pharmacol. 2009, 603 (Suppl. S1-S3), 42-49. [CrossRef] 
21. Di Filippo, C.; Trotta, M.C.; Maisto, R.; Siniscalco, D.; Luongo, M.; Mascolo, L.; Alfano, R.; Accardo, M.; Rossi, C.; Ferraraccio, F.; et al. Daily Oxygen $/ \mathrm{O}_{3}$ Treatment Reduces Muscular Fatigue and Improves Cardiac Performance in Rats Subjected to Prolonged High Intensity Physical Exercise. Oxid. Med. Cell Longev. 2015, 2015, 190640. [CrossRef] [PubMed]

22. Rowen, R.J.; Robins, H. Ozone Therapy for Complex Regional Pain Syndrome: Review and Case Report. Curr. Pain Headache Rep. 2019, 23, 41. [CrossRef]

23. Zänker, K.S.; Kroczek, R. In vitro synergistic activity of 5-fluorouracil with low-dose ozone against a chemoresistant tumor cell line and fresh human tumor cells. Chemotherapy 1990, 36, 147-154. [CrossRef] [PubMed]

24. Cannizzaro, A.; Verga Falzacappa, C.V.; Martinelli, M.; Misiti, S.; Brunetti, E.; Bucci, B. O(2/3) exposure inhibits cell progression affecting cyclin B1/cdk1 activity in SK-N-SH while induces apoptosis in SK-N-DZ neuroblastoma cells. J. Cell Physiol. 2007, 213, 115-125. [CrossRef] [PubMed]

25. Afrin, F.; Chi, M.; Eamens, A.L.; Duchatel, R.J.; Douglas, A.M.; Schneider, J.; Gedye, C.; Woldu, A.S.; Dun, M.D. Can Hemp Help? Low-THC Cannabis and Non-THC Cannabinoids for the Treatment of Cancer. Cancers 2020, 12, 1033. [CrossRef] [PubMed]

26. Nabissi, M.; Morelli, M.B.; Offidani, M.; Amantini, C.; Gentili, S.; Soriani, A.; Cardinali, C.; Leoni, P.; Santoni, G. Cannabinoids synergize with carfilzomib, reducing multiple myeloma cells viability and migration. Oncotarget 2016, 7, 77543-77557. [CrossRef]

27. Velasco, G.; Sánchez, C.; Guzmán, M. Anticancer mechanisms of cannabinoids. Curr. Oncol. 2016, 23, S23-S32. [CrossRef]

28. Marinelli, O.; Morelli, M.B.; Annibali, D.; Aguzzi, C.; Zeppa, L.; Tuyaerts, S.; Amantini, C.; Amant, F.; Ferretti, B.; Maggi, F.; et al. The Effects of Cannabidiol and Prognostic Role of TRPV2 in Human Endometrial Cancer. Int. J. Mol. Sci. 2020, 21, 5409. [CrossRef]

29. Jeong, S.; Yun, H.K.; Jeong, Y.A.; Jo, M.J.; Kang, S.H.; Kim, J.L.; Kim, D.Y.; Park, S.H.; Kim, B.R.; Na, Y.J.; et al. Cannabidiol-induced apoptosis is mediated by activation of Noxa in human colorectal cancer cells. Cancer Lett. 2019, 447, 12-23. [CrossRef]

30. Morelli, M.B.; Offidani, M.; Alesiani, F.; Discepoli, G.; Liberati, S.; Olivieri, A.; Santoni, M.; Santoni, G.; Leoni, P.; Nabissi, M. The effects of cannabidiol and its synergism with bortezomib in multiple myeloma cell lines. A role for transient receptor potential vanilloid type-2. Int. J. Cancer 2014, 134, 2534-2546. [CrossRef]

31. Michalski, C.W.; Oti, F.E.; Erkan, M.; Sauliunaite, D.; Bergmann, F.; Pacher, P.; Batkai, S.; Müller, M.W.; Giese, N.A.; Friess, H.; et al. Cannabinoids in pancreatic cancer: Correlation with survival and pain. Int. J. Cancer 2008, 122, 742-750. [CrossRef] [PubMed]

32. Fogli, S.; Nieri, P.; Chicca, A.; Adinolfi, B.; Mariotti, V.; Iacopetti, P.; Breschi, M.C.; Pellegrini, S. Cannabinoid derivatives induce cell death in pancreatic MIA PaCa-2 cells via a receptor-independent mechanism. FEBS Lett. 2006, 580, 1733-1739. [CrossRef]

33. Ferro, R.; Adamska, A.; Lattanzio, R.; Mavrommati, I.; Edling, C.E.; Arifin, S.A.; Fyffe, C.A.; Sala, G.; Sacchetto, L.; Chiorino, G.; et al. GPR55 signalling promotes proliferation of pancreatic cancer cells and tumour growth in mice, and its inhibition increases effects of gemcitabine. Oncogene 2018, 37, 6368-6382. [CrossRef] [PubMed]

34. Donadelli, M.; Dando, I.; Zaniboni, T.; Costanzo, C.; Dalla Pozza, E.; Scupoli, M.T.; Scarpa, A.; Zappavigna, S.; Marra, M.; Abbruzzese, A.; et al. Gemcitabine/cannabinoid combination triggers autophagy in pancreatic cancer cells through a ROS-mediated mechanism. Cell Death Dis. 2011, 2, e152. [CrossRef]

35. Orth, M.; Metzger, P.; Gerum, S.; Mayerle, J.; Schneider, G.; Belka, C.; Schnurr, M.; Lauber, K. Pancreatic ductal adenocarcinoma: Biological hallmarks, current status, and future perspectives of combined modality treatment approaches. Radiat. Oncol. 2019, 14, 141. [CrossRef] [PubMed]

36. Manji, G.A.; Olive, K.P.; Saenger, Y.M.; Oberstein, P. Current and Emerging Therapies in Metastatic Pancreatic Cancer. Clin. Cancer Res. 2017, 23, 1670-1678. [CrossRef]

37. Conroy, T.; Desseigne, F.; Ychou, M.; Bouché, O.; Guimbaud, R.; Bécouarn, Y.; Adenis, A.; Raoul, J.L.; Gourgou-Bourgade, S.; de la Fouchardière, C.; et al. FOLFIRINOX versus gemcitabine for metastatic pancreatic cancer. N. Engl. J. Med. 2011, 364, 1817-1825. [CrossRef]

38. Muller, C.; Morales, P.; Reggio, P.H. Cannabinoid Ligands Targeting TRP Channels. Front. Mol. Neurosci. 2019, 11, 487. [CrossRef] 
39. De Petrocellis, L.; Nabissi, M.; Santoni, G.; Ligresti, A. Actions and Regulation of Ionotropic Cannabinoid Receptors. Adv. Pharmacol. 2017, 80, 249-289. [CrossRef]

40. Carracedo, A.; Gironella, M.; Lorente, M.; Garcia, S.; Guzmán, M.; Velasco, G.; Iovanna, J.L. Cannabinoids induce apoptosis of pancreatic tumor cells via endoplasmic reticulum stress-related genes. Cancer Res. 2006, 66, 6748-6755. [CrossRef]

41. Guo, X.; Ling, X.; Du, F.; Wang, Q.; Huang, W.; Wang, Z.; Ding, X.; Bai, M.; Wu, Z. Molecular Imaging of Pancreatic Duct Adenocarcinoma Using a Type 2 Cannabinoid Receptor-Targeted Near-Infrared Fluorescent Probe. Transl. Oncol. 2018, 11, 1065-1073. [CrossRef] [PubMed]

42. Roberto, D.; Klotz, L.H.; Venkateswaran, V. Cannabinoid WIN 55,212-2 induces cell cycle arrest and apoptosis, and inhibits proliferation, migration, invasion, and tumor growth in prostate cancer in a cannabinoid-receptor 2 dependent manner. Prostate 2019, 79, 151-159. [CrossRef] [PubMed]

43. Kuroda, K.; Azuma, K.; Mori, T.; Kawamoto, K.; Murahata, Y.; Tsuka, T.; Osaki, T.; Ito, N.; Imagawa, T.; Itoh, F.; et al. The Safety and Anti-Tumor Effects of Ozonated Water in Vivo. Int. J. Mol. Sci. 2015, 16, 25108-25120. [CrossRef] [PubMed]

44. Nabissi, M.; Morelli, M.B.; Santoni, M.; Santoni, G. Triggering of the TRPV2 channel by cannabidiol sensitizes glioblastoma cells to cytotoxic chemotherapeutic agents. Carcinogenesis 2013, 34, 48-57. [CrossRef] [PubMed]

45. Du, J.; Nelson, E.S.; Simons, A.L.; Olney, K.E.; Moser, J.C.; Schrock, H.E.; Wagner, B.A.; Buettner, G.R.; Smith, B.J.; Teoh, M.L.; et al. Regulation of pancreatic cancer growth by superoxide. Mol. Carcinog. 2013, 52, 555-567. [CrossRef] [PubMed]

46. Poma, A.; Colafarina, S.; Aruffo, E.; Zarivi, O.; Bonfigli, A.; Di Bucchianico, S.; Di Carlo, P. Effects of ozone exposure on human epithelial adenocarcinoma and normal fibroblasts cells. PLoS ONE 2017, 12, e0184519. [CrossRef]

47. Jones, S.; Zhang, X.; Parsons, D.W.; Lin, J.C.; Leary, R.J.; Angenendt, P.; Mankoo, P.; Carter, H.; Kamiyama, H.; Jimeno, A.; et al. Core signaling pathways in human pancreatic cancers revealed by global genomic analyses. Science 2008, 321, 1801-1806. [CrossRef]

48. Raphael, B.J.; Hruban, R.H.; Aguirre, A.J.; Moffitt, R.A.; Yeh, J.J.; Stewart, C.; Robertson, A.G.; Cherniack, A.D.; Gupta, M. Cancer Genome Atlas Research Network. Integrated Genomic Characterization of Pancreatic Ductal Adenocarcinoma. Cancer Cell. 2017, 32, 185-203.e13. [CrossRef]

49. Roberts, N.J.; Norris, A.L.; Petersen, G.M.; Bondym, M.L.; Brand, R.; Gallinger, S.; Kurtz, R.C.; Olson, S.H.; Rustgi, A.K.; Schwartz, A.G.; et al. Whole Genome Sequencing Defines the Genetic Heterogeneity of Familial Pancreatic Cancer. Cancer Discov. 2016, 6, 166-175. [CrossRef]

50. Buscail, L.; Bournet, B.; Cordelier, P. Role of oncogenic KRAS in the diagnosis, prognosis and treatment of pancreatic cancer. Nat. Rev. Gastroenterol. Hepatol. 2020, 17, 153-168. [CrossRef]

51. Collisson, E.A.; Trejo, C.L.; Silva, J.M.; Gu, S.; Korkola, J.E.; Heiser, L.M.; Charles, R.P.; Rabinovich, B.A.; Hann, B.; Dankort, D.; et al. A central role for RAF $\rightarrow$ MEK $\rightarrow$ ERK signaling in the genesis of pancreatic ductal adenocarcinoma. Cancer Discov. 2012, 2, 685-693. [CrossRef] [PubMed]

52. Eser, S.; Reiff, N.; Messer, M.; Seidler, B.; Gottschalk, K.; Dobler, M.; Hieber, M.; Arbeiter, A.; Klein, S.; Kong, B.; et al. Selective requirement of PI3K/PDK1 signaling for Kras oncogene-driven pancreatic cell plasticity and cancer. Cancer Cell 2013, 23, 406-420. [CrossRef] [PubMed]

53. Altomare, D.A.; Tanno, S.; de Rienzo, A.; Klein-Szanto, A.J.; Tanno, S.; Skele, K.L.; Hoffman, J.P.; Testa, J.R. Frequent activation of AKT2 kinase in human pancreatic carcinomas. J. Cell Biochem. 2002, 87, 470-476. [CrossRef] [PubMed]

54. Ying, H.; Dey, P.; Yao, W.; Kimmelman, A.C.; Draetta, G.F.; Maitra, A.; DePinho, R.A. Genetics and biology of pancreatic ductal adenocarcinoma. Genes Dev. 2016, 30, 355-385. [CrossRef] [PubMed]

55. Contis, J.; Lykoudis, P.M.; Goula, K.; Karandrea, D.; Kondi-Pafiti, A. Survivin expression as an independent predictor of overall survival in pancreatic adenocarcinoma. J. Cancer Res. Ther. 2018, 14 (Suppl. S14), S719-S723. [CrossRef] [PubMed]

56. Papademetrio, D.L.; Lompardía, S.L.; Simunovich, T.; Costantino, S.; Mihalez, C.Y.; Cavaliere, V.; Álvarez, É. Inhibition of Survival Pathways MAPK and NF-kB Triggers Apoptosis in Pancreatic Ductal Adenocarcinoma Cells via Suppression of Autophagy. Target. Oncol. 2016, 11, 183-195. [CrossRef]

57. Schmitt, A.; Feldmann, G.; Zander, T.; Reinhardt, H.C. Targeting Defects in the Cellular DNA Damage Response for the Treatment of Pancreatic Ductal Adenocarcinoma. Oncol. Res. Treat. 2018, 41, 619-625. [CrossRef] [PubMed] 
58. Cao, L.; Li, W.; Kim, S.; Brodie, S.G.; Deng, C.X. Senescence, aging, and malignant transformation mediated by 553 in mice lacking the Brca1 full-length isoform. Genes Dev. 2003, 17, 201-213. [CrossRef]

59. Carlos, A.R.; Escandell, J.M.; Kotsantis, P.; Suwaki, N.; Bouwman, P.; Badie, S.; Folio, C.; Benitez, J.; Gomez-Lopez, G.; Pisano, D.G.; et al. ARF triggers senescence in Brca2-deficient cells by altering the spectrum of p53 transcriptional targets. Nat. Commun. 2013, 4, 2697. [CrossRef]

60. Heijink, A.M.; Talens, F.; Jae, L.T.; van Gijn, S.E.; Fehrmann, R.S.N.; Brummelkamp, T.R.; van Vugt, M.A.T.M. BRCA2 deficiency instigates cGAS-mediated inflammatory signaling and confers sensitivity to tumor necrosis factor-alpha-mediated cytotoxicity. Nat. Commun. 2019, 10, 100. [CrossRef]

61. Yako, Y.Y.; Kruger, D.; Smith, M.; Brand, M. Cytokines as Biomarkers of Pancreatic Ductal Adenocarcinoma: A Systematic Review. PLoS ONE 2016, 11, e0154016. [CrossRef] [PubMed]

62. Ling, J.; Kang, Y.; Zhao, R.; Xia, Q.; Lee, D.F.; Chang, Z.; Li, J.; Peng, B.; Fleming, J.B.; Wang, H.; et al. KrasG12D-induced IKK2/ $\beta / \mathrm{NF}-\mathrm{kB}$ activation by IL-1 $\alpha$ and $\mathrm{p} 62$ feedforward loops is required for development of pancreatic ductal adenocarcinoma. Cancer Cell 2012, 21, 105-120. [CrossRef] [PubMed]

63. Hausmann, S.; Kong, B.; Michalski, C.; Erkan, M.; Friess, H. The role of inflammation in pancreatic cancer. Adv. Exp. Med. Biol. 2014, 816, 129-151. [CrossRef] [PubMed]

64. Kunnumakkara, A.B.; Guha, S.; Krishnan, S.; Diagaradjane, P.; Gelovani, J.; Aggarwal, B.B. Curcumin potentiates antitumor activity of gemcitabine in an orthotopic model of pancreatic cancer through suppression of proliferation, angiogenesis, and inhibition of nuclear factor-kappaB-regulated gene products. Cancer Res. 2007, 67, 3853-3861. [CrossRef] [PubMed]

65. Pfaffl, M.W. A new mathematical model for relative quantification in real-time RT-PCR. Nucleic Acids Res. 2001, 29, e45. [CrossRef] [PubMed]

66. Chou, T.C. Theoretical basis, experimental design, and computerized simulation of synergism and antagonism in drug combination studies. Pharmacol. Rev. 2006, 58, 621-681. [CrossRef]

(C) 2020 by the authors. Licensee MDPI, Basel, Switzerland. This article is an open access article distributed under the terms and conditions of the Creative Commons Attribution (CC BY) license (http://creativecommons.org/licenses/by/4.0/). 